Puteri Shireen Jahn Kassim ${ }^{1}$

ORCID: 0000-0003-1139-5485

Kamariah Kamaruddin ${ }^{2}$

ORCID: 0000-0001-8591-4482

Illyani Ibrahim ${ }^{3}$

ORCID: 0000-0001-8154-5579

Nor Zalina Harun 4

ORCID: 0000-0001-9269-1483

\title{
A TROPICALIZED URBAN DESIGN FRAMEWORK FROM MORPHOLOGICAL PATTERNS OF PRE-COLONIAL MARITIME CENTERS OF THE MALAY WORLD
}

\footnotetext{
${ }^{1}$ Associate Professor, Kulliyyah of Architecture and Environmental Design, International Islamic University Malaysia

${ }^{2}$ Postgraduate, International Islamic University Malaysia

${ }^{3}$ Assistant Professor, Kulliyyah of Architecture and Environmental Design, International Islamic University Malaysia

${ }^{4}$ Associate Professor and Senior Research Fellow, ATMA, UKM
}

Keywords: tropical urban design, tropical neo-traditional urbanism, South East Asian traditional urbanism, Malay urban morphology

\begin{abstract}
Patterns from studies in past urban morphologies have come under scrutiny recently due to the rise of authenticity in urban regeneration fields and the resurgences in the search for culturally-rooted, and sustainable, principles of urban design. Towards an improved place-making potential while complying with rising sustainable standards, the tropical region have a rich heritage of the Malay Nusantara pre-colonial 'original' urban patterns - which are essentially South East Asian riverine or maritime cities of the $15_{\text {th }}$ to the $18_{\text {th }}$ centuries straddling the Malay Peninsular and Borneo. This paper highlights the morphology studies of such centers, but focuses primarily on urban core patterns of cities such as Alor Setar (a city on the north of the Malay Peninsula), Kuala Kangsar (to the north-east, more towards inland), Melaka (a maritime city towards the south) and Pontianak, Kalimantan (west of Borneo) which layers of past patterns can be studied. It attempts to recreate an era which is known as 'precolonial' in the Malay world, whose urban grain and form still embraces ecological and 'local' principles and whose dense and compact forms are linked closely with rivers and seas. An attempt is then made to build a conceptual framework of urban design characteristics based on the findings; including features and strategies towards enhancing typical bioclimatic principles to encompass a range of visual and aesthetic concepts which embraces the notion of familiarity and cultural continuity arising from lessons learnt from vernacular forms and past settlements. As many of these sites have undergone sedimentation and development, the paper reconstructs the past based on historical data, maps and documents and then compares these reconstructed forms with those of colonial and post-colonial patterns. It is forwarded that the Malay urban core in pre-colonial times is distinctive for its natural growth and its ecological and climatic credentials, such as orientation and compactness, while the post-colonial patterns are more spread out and gridded configurations losing the original permeability.
\end{abstract}

\section{PLANOWANIE PRZESTRZENNE W MIASTACH TROPIKALNYCH NA PODSTAWIE WZORÓW MORFOLOGICZNYCH PRZEDKOLONIALNYCH MALAJSKICH OŚRODKÓW NADMORSKICH}

Slowa kluczowe: planowanie przestrzenne w miastach tropikalnych, tropikalna urbanistyka nawiązująca do tradycji, tradycyjna urbanistyka Azji Południowo-Wschodniej, morfologia 


\begin{abstract}
Abstrakt
Zagadnienia dotyczące struktury przestrzennej miasta zaczęto ostatnio dokładniej badać z uwagi na wzrost zainteresowania autentycznym dziedzictwem kulturowym i turystyką oraz poszukiwanie zakorzenionych w kulturze, więc bardziej zrównoważonych, zasad planowania przestrzeni miejskiej. W aspekcie poprawy potencjału miejskiego w rejonach tropikalnych, $w$ tym w rejonie Nusantara, szczególne zainteresowanie budzą przedkolonialne „oryginalne” układy urbanistyczne miast nadrzecznych lub nadmorskich Azji Południowo-Wschodniej, powstające od XV do XVIII wieku na Półwyspie Malajskim i Borneo. Praca ta rzuca światło na tego rodzaju badania, a skupia się przede wszystkim na takich miastach, jak: Alor Setar (zlokalizowane na północy Półwyspu Malajskiego), Kuala Kangsar (na północnym wschodzie, ale skierowane bardziej w stronę lądu), Malaka (nadmorskie miasto na południu) oraz Pontianak, Kalimantan (zachodnia część Borneo). Podjęto próbę odtworzenia ery zwanej 'przedkolonialną' w realiach Malajów, które są ściśle związane z rzekami i morzem. Podjęto próbę utworzenia ramowej koncepcji projektowania urbanistycznego, którego cechy są silnie związane z klimatem tropikalnym. Chodzi więc o wzmocnienie typowych zasad bioklimatycznych, w oparciu o które stworzono wizualizacje inspirowane rodzimymi formami dawnego osadnictwa. Zanim pojawiły się obce wpływy, malajskie centra miast w przeszłości związane były z wybrzeżem i nadbrzeżami rzek, później kolonizacja doprowadziła do rozerwania i fragmentacji. Ponieważ wiele z tych miejsc pokryły osady (sedymentacja), praca dokonuje rekonstrukcji w oparciu o dane historyczne, mapy i dokumenty, a następnie porównuje te rekonstrukcje z formami i układami urbanistycznymi z czasów kolonialnych. Wykazano, że malajski rdzeń miasta w czasach przedkolonialnych wyróżnia się naturalnym wzrostem oraz dostosowaniem do warunków ekologicznych i klimatycznych, dzięki układowi i spójności, podczas gdy wzory postkolonialne są bardziej rozprzestrzenione i tracą oryginalną przejrzystość.
\end{abstract}

\section{INTRODUCTION}

Urban morphology, or studies in the morphology of urban settlements in traditional times have risen recently due to the global interest in authenticity studies and development of locally-developed guidelines of sustainable urbanism. Pre-colonial patterns in South East Asia is of interest, due to the significant 'rupture' or changes wrought by colonial forces and influences during the colonial period in cities within regions such as Malaysia, Indonesia and Singapore. Thus in such sites, and settlements, the original patterns of the local settlements have been sedimented over repeatedly, causing a loss of recognizable patterns arising from the vernacular and the local. This paper attempts to highlight such changes, including a reconstruction through mapping the pre-colonial patterns of 'the urban' core of such settlements, and then comparing it with other eras which can be defined as post-colonial. In the case of the four cities selected for study, the precolonial cities of Alor Setar, Kuala Kangsar, Melaka and Pontianak is compared with a post-colonial form which in some cases is defined as present time, while in others (where past maps) are found is defined as an urban pattern during colonial control. This paper is an attempt to reconstruct such cities, and to semantically describe the urban design principles and their concepts that can arise from such studies. It is contended that a framework that conceptualizes and semantically describes these strategies is crucial for their sustainability in future.

Prior to external influences, these Malay urban centres were closely related to a natural evolvement of mar- itime and riverine environments before the rupture and fragmentation caused by its colonization history. There has been studies in South East Asia to relook back at the past patterns of its settlements, and its urban cores. For example, the $\mathrm{PhD}$ thesis of Widya Fransiska (2013) looked closely at the morphology of Palembang in order to highlight strategies of rebranding, identity-making and conservation for the city Mustikawi et al. (2018) highlighted the peculiar key grid patterns and urban open spaces which defined the strong socio-cultural potential in the region. Hence particularly, the morphology of riverside settlement and maritime traditional cities in South East Asia before being disrupted by colonial or external influences are unique and of particular interest, as these can be unearth to capture the traditional identities of a tropical site in order not only to re-build the city's identity, but contribute in bringing closer to level of environmental sustainability. The physical and spatial patterns of an urban core are of particular interest, as the urban core represents enhanced and elevated identities of communities that contain urban design essences and patterns of ways of life that straddles maritime or riverside settlement. To further study these patterns, the paper aims at reconstructing the urban core patterns which have disappeared over decades and centuries. Links between urban morphology and identity of set-element, development and change was also sought. Through using historical documents, travel descriptions, historical studies and travelogues, a pattern of past urban core morphologies emerges and is reconstructed. The aim, eventually, is to reconceptualise a framework of trop- 
icalized urban design principles from these traditional patterns which can characterize essences and criteria of urban design that arise from these traditional patterns.

Historically, ethnographers and historians have categorized settlements or civilizations in Malay-Nusantara region as 'inland' and 'coastal' or pesisir (Reid, 2012, Andaya, 2010). Inland civilizations are characterized by a central, mainly gridded layout and masonry-based buildings, typical of early civilizations. They spread across large inland areas and have a strong and ordered centre, while the 'coastal' civilizations have often been described as 'ungridded' and 'disordered'. However, these studies attempt to highlight a certain order does exists within these coastal cities. Past studies have also indicated that the inland cities have arisen essentially from earlier non-Islamic socio-religious traditions into its Islamic traditions, while the coastal or pesisir ones have risen originally from Islamic era or influences.

\section{Tropical urban design - present theories}

Tropical urban design and its principles have been discussed by many researchers, theorists and practitioners; including Yeang (1987) in his seminal 'Tropical Urban Regionalism', Harun and Abdullah (2018) and Kamaruddin et al. (2018). In terms of urban policy, guidelines for the tropical city and urban life under eco-climatic conditions have been parts of urban policy as outline, promulgated and practiced by the Singapore Urban Authority and Cairns (Australia) Municipal authority. In all these cases, certain principles emerge which aligns with global developments of a green urbanism worldwide. It recalls how Carmona (2010) summates that recent developments in urban design is increasingly concerned with 'an emerging tradition of sustainable urbanism' and Brown's et al. (2009) identified 'four convergent lines of thinking in sustainable urbanism; 1) the need for vibrant walkable neighborhoods that attract creative classes (ii) the emergence of downtowns of increasing demand for urban living; an awareness of the growing obesity which has spread due to car dependent urbanism; (iv) the growing interest in the potential of urban form to reduce the carbon footprint of mankind'. Due to the rapid rate of development in Asia, more should be studied with regards to vernacular forms and principles, including culturally-rooted concepts underlying the constant roots of towns that have disappeared due to the rupture and layers of de- velopment that some sites and centers have encountered. The overall approach in architecture and urban design of the present days is towards reinvigorating the past as sustainability has been termed as 'recalling the forgotten past' and thus the forgotten principle of past traditions also highlight the crucial role of phenomenology - an approach to urban design which favors human experiences and senses such as light, shade, breeze and cool comfort which aims to cause and initiate the simultaneous experience, occurrence and optimisation of climatic comfort and total experience of the human being.

In contrast to present urban life confined the residents indoors and under homogenous conditions, the past descriptions of tropical cities highlighted the role of external spaces and light, air and greenery. For example, 16th century travellers such as Eredia to Melaka, remarked and observed that the climate was 'salubrious' and there was continuous cool comfort. Such conditions demanded that several aspects occurred simultaneously, because it was necessary to have the simultaneous impact of visual, thermal and optical surroundings and parameters linked with the social, spiritual, physical and environmental elements of one's surroundings. The tropics is a region in which climate is highly intense, the experience of the tropical climate combines rain, sun and light, and hence the experience of tropical traditional cities or settlements, have been described vividly and contain experiences of elements of air, water and light, including monsoonal storms and breaking sunlight. These climatic elements should combine the inherent principles of vernacular architecture of the tropics such as elevated forms, large layered roofs and wide windows in order to give a phenomenological experience or a specific tropical experience of the tropical city. Hence it is crucial again to investigate past morphologies which can recreate a climatic and phenomenological model for urbanism in the tropics. In tropical Asia, such patterns include the descriptions of the Malay maritime urban cores which contain essentially a description of Malay urban design forms, space and patterns before the 'layering;' or 'disturbance' of colonialism. Although the colonialist in many cases had maintained a close link to the tropical context in their architecture and urban design, it is still necessary to unearth the past vernacular patterns in order to allow these to become a model of environmentalism which developed naturally and spontaneously under tropical conditions. Although often, these vernacular settlements or 
sites suffer from a perception that they have been random and organic developments without any planning, it is still necessary to unearth common and shared traits amongst the patterns.

This paper contends that a vernacular perspective in urban design and planning is particularly crucial in these riverine and maritime cities as intense sedimentary layers changes have overlapped it. Additionally, to achieve the present standards of sustainability, one must try to conceptualize and outline key urban design strategies that necessitate a deep understanding of past patterns of the locality before disturbances were fraught by external forces. These patterns reflect the seam-less integration of bio-climatically conscious vernacular buildings and natural elements of its urban landscape or settlements; such that such strategies recall present emerging green holistic environmental principles. As Caliskan and Marshall (2011) summate: Implicit in the argument of past urbanist, is that with better integration of urban morphological studies, urban designers creating urban compositions risk improved solutions must do so with good understanding of urban fabrics, including its original vernacular-rooted patterns in order not only to create better place-identities, but more sustainable ones. Malay urban traditional centers are amongst the vernacular patterns that consists of past histories of the regions, and its study can go towards demonstrating strategies that can assist towards the low carbon agenda and ethic of sustainable development. One cannot exist without the other, as both vernacular architecture and urban design principles are crucial in creating a bioclimatic environment, within which the green elements and spatial layout of building, construct sustainable urbanism strategies to induce increased walkability, permeability and reduced urban heat island impact while attaining cooler outdoor comfort in the city.

\section{AIMS AND OBJECTIVES}

This paper, attempts to look at the urban morphology, focusing on the urban core patterns of the traditional and pre-colonial Malay public realm, which can be generally defined as the public realm which surrounds the administrative centers of the traditional Malay world. There are a range of aims, yet to name a few, including as follows:

1. to reenact an estimation of the urban core morphology of past settlements of the Malay world;

2. to compare the pattern with that of post-colonial or colonial patterns;
3. to highlight the ecological reasoning or wisdom of the pre and post-colonial patterns;

4. to reframe the elements of a theoretical framework of Malay tropicalized urban design arising; from this and to improve the understanding of their past urban morphologies.

\section{METHODOLOGY}

The methodology can be generally divided into two parts, the first part consisting of a historical research, and the second part consists of a modeling process. Both parts were undertaken concurrently. As the historical research shed light on the morphology, successive and continuous amendment were done to the drawings and models. Throughout this process and method, the first part was based on historical documents, including travelogues and lithographs, historical data, visual documentation and historical studies, the aim is to reconstruct the key elements of the urban core pattern or morphology of the pre-colonial era of the Malay world. Focusing on certain sites, which range from those closest to and furthest away from Colonial control, including Kuala Kangsar, Alor Setar and Pontianak, Kalimantan, the aim is to reconstruct these patterns including the location of key structures. It is hypothesized that these urban systems were patterns that emerge from a deep and intrinsic understanding of their innate environments. The mapping is undertaken simultaneously with a historical study of the site focusing on how the site came under colonial rule to establish the extent of such changes and influences. The aim is to characterize the pre-colonial urban patterns and attempt to enact the wisdoms and principles that infused urban life of the past.

\section{Part 2: Reconstruction, modeling and mapping}

Reconstruction of the appearance of the Malay urban core centers and their morphological character and elements is undertaken by compiling all the past images, including drawings and lithographs. There are few case studies of the original Malay palaces available. Due to the fragile nature of timber, many of these palaces no longer exist. The palaces show how the traditional Malay society reflected their climatic and ecological conditions in the Malay urban core of the past. Hence, certain reconstruction and mapping need to take place. Figures 1 and 2, taken from these studies, represent the 
process of reconstruction of certain palatial centers such as Melaka in the 16th century, and the original center of Kuala Kangsar, which is Lembah Sayung, which highlighted the positioning and layout of such urban centers. In all cases, the reconstruction of past traditional Malay world, the ,public realm' is the open public linkage of such recurring components of the key public structures such as the istana-palace, the masjid-mosque and the padang or alun alun - open field between them, and the medan - an open market space attached to the commercial center of which the arrangement and configuration slightly differ due to adaptation to different location, terrain and setting. This public realm is bounded and shows the features of interfacing spaces such as semi-open enclosures at the end and surrounding the public building such as Balai Besar - audience hall and the masjid mosque. Other features such as the city wall, fencing and screening device and gateways suggest the limits of the center to the public and the formal entrance way in order of respect by which to enter. Other embellishing features are the serambi - verandah, anjung - porticos, kolong space under the floor and wakaf/bangsal - pavilion or shed. They not only provide shaded spaces for comfort in the distance walkable for the public within the urban realm, but also function as buffer from the topical heat and sunshine, thus cooling the interior of the building. Another non separable feature of the Malay public realm is the incorporation of nature in the form of large trees, pools and flowering fragrant plants that further and enhanced the coolness and ambience of the public space.

The buildings are modeled based on manuscripts, historical texts, lithographs and old photographs and further scaled using AutoCAD and 3D Studio Max:

1) estimated length of building structures and limitation of spanning column to column, opening size and height of floor to floor based on the idea of technology such as the masonry stonework or brickwork and the timber construction available in the 1600s;

2) estimating the walkable distance of the city and assessing permeability within the city framework;

3) extrapolating the area of built up areas in comprison to the natural landscape within a specific area of the city based on population extracted from historical texts and manuscripts;

4) estimating how the growth of the city take shape hence configured, clustered compact and linear.
Initially, scaled google maps were used as base plans. Important geographical features such as rivers, main streets, blocks, the coastal line, thick vegetation and swamp areas were then traced out. The process of constructing the morphological construction plan is, as shown in fig. 1., super imposed over the google map. Location of main features on 3D maps and images is transferred and adjusted accordingly on to the present google map as such to fit into the framework between the coastal line, the river, the streets and the natural vegetation and angles adjusted to match the view of old paintings, Portuguese and Dutch lithographs. The density is estimated through the population of the city reported in historical reports and documents which can be cross checked by placing in the habitable units based on density per acre e.g. $150 \mathrm{~m}$ width along the water front.

\section{THE MALAY COSMOGRAPHY- ATTITUDES TOWARDS THEIR ENVIRONMENT AND ITS BOUNDARIES}

Ethnic Malays live not only throughout the Peninsula of West Malaysia, and in the coastal area of East Malaysia. They are also found in Brunei, southern Thailand, parts of Sumatra, Java, the Riau islands and Kalimantan in Indonesia, southern Philippines, and even as far as Colombo, Sri Lanka, and Cape Town, South Africa, as well as in Cambodia and Vietnam (known as 'Chams'). Two thousand years of non-stop traffic between India and the archipelago, as well as with China, Champa and Cambodia, provided a plethora of cultural influences through trade, culture and inter-marriages. Traditionally the Malay society was made of a close-knit feudal organization that reflected sharp divisions between nobility and commoners (The Sejarah Melayu ${ }^{1}$ ).

Malay nations did not constitute the national boundaries, as known today but essentially was made of Sultanates with populations and followers within geographically estimated regions, often with no clearly defined geographical boundaries, but more dependent

1 The Malay Annals (Malay: Sejarah Melayu), originally titled Sulalatus Salatin (Genealogy of Kings) is a literary work that gives a narrative history of the origin, evolution and demise of the Malay maritime empire, the Malacca Sultanate. The work which was composed sometime between 15 th and 16 th centuries, is considered one of the finest literary and historical works in the Malay language. 
upon population-based settlements and reach. Milner (2011) aptly describes the nature of the Malay traditional polity as '...The ruler as an institution ... appears to have been an axial component in the lifeworld of the community. It was the ruler, not a priest class ... who dominated... The surroundings of the ruler's center of residence and administration ... known as kedatuan in ancient inscriptions...' Milner (2011) further termed kedatuan '... as empire or royal center... of no direct equivalent in the English language.'

Tarling (1999; 197) gives a useful concept of how Malays saw their environment in the past:

'... In traditional Malay belief, both the source of river waters and the home of ancestral spirits were high on the mountain slopes; the highest reaches of the mountains were thus thought of as holy places and the source of beneficent forces that bestowed well-being upon the people.

The critical link between these two forces of mountain and sea were the rivers, for they were the channels through which the rainwater that fell on the mountains flowed down, ultimately to merge with the sea. These river basins contained the earliest polities of island South East Asia... 'and shaped the political dynamic between them;

Tarling $(1999 ; 173)$ further describes the origins of the Malay world as we know today: '...The process of political organization set in motion among the Malay leaders by this new source of wealth reached a critical phase during the last half of the 7th century when rulers near Palembang, on the Musi river of South East Sumatera achieve a position of paramountcy.'

The observations of Tarling $(1999 ; 197)$ of the Malay cultural worldview, which gave rise to its urbanism and settlement patterns is particularly crucial: '...In the traditional Malay view of the world there was a powerful duality, a landscape dominated by high and steep mountains and seas whose horizons seem unreachable...' Wind and water takes a critical role in the Malay world as both structures and landscape elements were environmentally and strategically laid out as to form an environmental fusion with the surrounding water resources. Traditionally Malay palaces are strategically placed near the river and oriented optimally to capture the prevailing wind.

However Gullick (1987) had observed the massive changes of the Malay society at the onset and trajectory of Colonization in the 19th century when the British and Dutch political control was first imposed in 1874 from what was previously a stable systems of Malay polities to the accelerating processes of social change of the 20th century which continue down to modern times during which Malaya, then later Malaysia, began to take shape, a watershed moment during which was void of benchmark for the measurement of change.

\section{EVOLVEMENT OF THE MALAY TRADITIONAL (PRE-COLONIAL) URBAN CENTERS}

While 'nagara-based' urban cores of past agrarian settlements are particularly well-known for their essentially ordered or 'semi-gridded' layouts and cardinal-based arrangements (Angkor, Majapahit) less is known of patterns of urban cores of 'negeri' (or maritime) based settlements, which evolved following the gradual disappearance of the 'nagara' ceremonial centers and civilizations by 13th to 14th centuries. Many of these maritime centers which grew due to trade-based activities within the archipelago we perceived as disordered, dense and organic. Yet on closer look, certain ordered patterns can be discerned and identified. Basically these grew inland and along the trade routes and these were located either at confluences of two rivers or at the mouth of large rivers, where according to Tar-ling (1999) represented how the Malay populations traditionally saw their ecological environment and its meaning : "the sea offered countless options for people who were at home in boats and where agriculturalists were dispersed in many small riverine enclaves". Researchers have even described such Malay settlements as originating from a form of 'paddle-culture' and some related the elevated structures and architecture to the mangrove eco-landscape from which many of these centers emerged.

The following results of morphological reconstruction summate the four centers with their palaces which were studied for their layout, two of which do not exist anymore but their orientation is reconstructed and the features of public realm that evolved from its configuration having certain climatic features are also derived. These palaces are from the 15th to 18th century as the 19th and 20th century palaces are no longer optimally designed with environmental energies, but they were a result of colonial interventions. These centers included: the Kota Melaka palace 1500s (fig. 1.1), the istana Seri Sayong site, Kuala Kangsar 1700's (fig. 1.2), the 
Balai Besar complex, Alor Setar original palace 1733 (fig. 1.3) and Istana Kadariah complex, Pontianak 1770 (fig. 1.4).

\section{RESULTS}

In terms of urban core, it was found that all urban cores of these settlements consisted of a center fronting an open field that represent royal enclaves, followed by other structures including mosques and artisan neighborhood, which are direct administrative apparatus and support structures under the monarch. This traditional surroundings or urban core parallels present maritime cities or river-based cities which grew at the confluence of rivers, but it has a more structured, some-times axial character and contains a high level of environmental and phenomenological strategies to ensure comfort conditions for the monarch and his families. The contextual climatic surroundings of Malay 'kedatuan' - kingdom architecture often designed for optimal comfort conditions amidst the intense tropical climate, with passive and ecological strategies including lush, green vegetation and capturing cooling breezes. Yet the climatic and low-carbon credential of such past forms and their contribution to present urban-environmental strategies are not adequately discussed. Nowadays, most research has typically been discussed as revolving around two principles i.e., ecology-landscape strategies and elements.

\section{THE PRE-COLONIAL PATTERNS OF THE MALAY URBAN CORE}

\subsection{Reconstructing $16^{\text {th }}$ century Kota Melaka}

Seen as an independent yet linked protectorate of China, yet an independent civilization, Melaka before 1511 was known as a state, a city and a port from which many came to trade. This neutral port of call housed many cultures and races which thrived on its location in the middle of the change of monsoonal winds. It was built from the trade activities of maritime South East Asia and had strategically grew midpoint between 'the turn of two monsoonal winds" and at the mouth of a large navigational river and deltaic plain, allowing ships to easily navigate and birth. Thus it strategically grew midpoint between "the turn of two monsoonal winds" and at the mouth of a large navigational river and del-

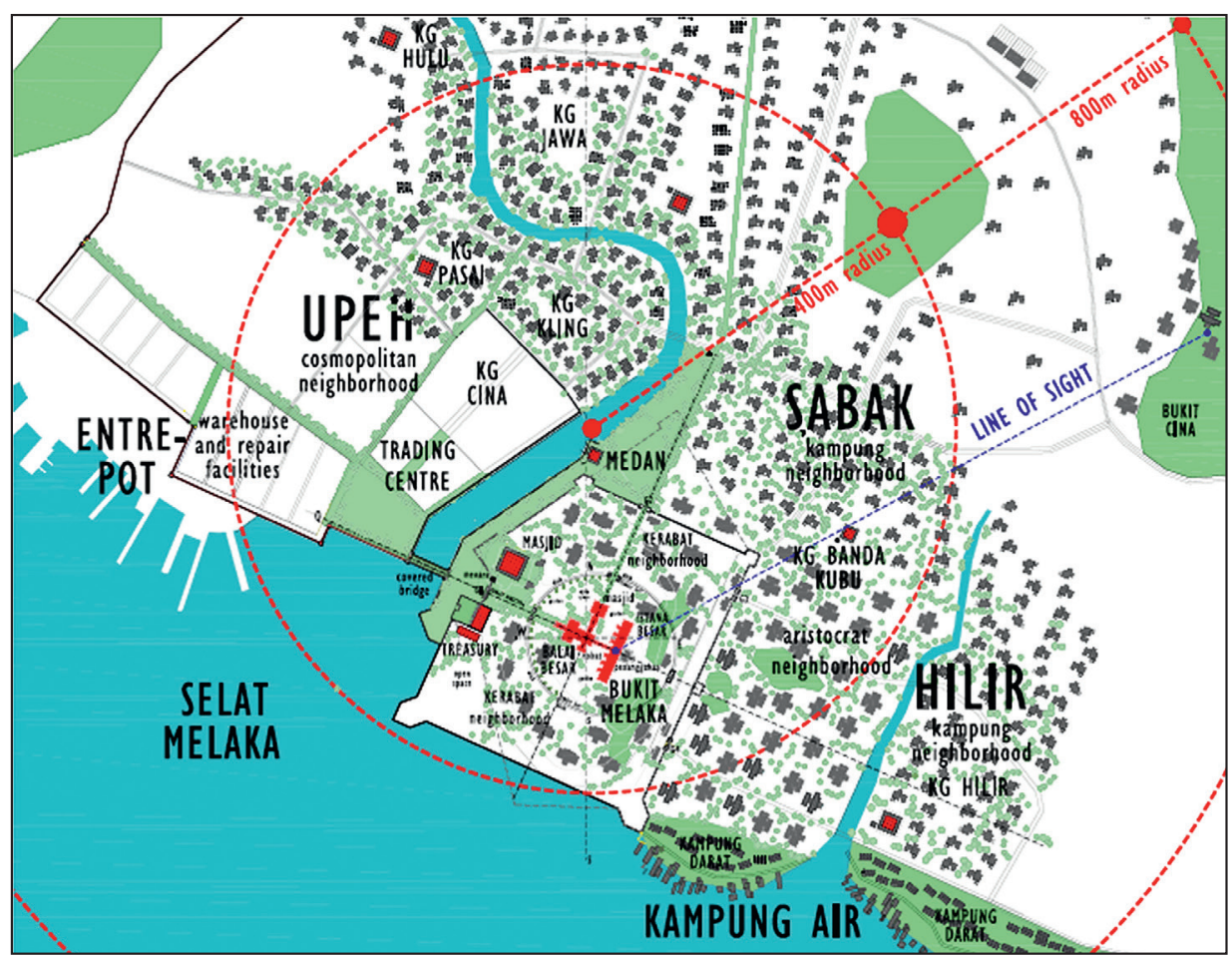

Fig. 1.1a Morphological Reconstruction urban core of pre-colonial Melaka. Kota Melaka (1511); @ Kamariah Kamaruddin Rys. 1.1a Rekonstrukcja morfologiczna przedkolonialnej Malaki (Melaki). Kota Melaka (1511); (C Kamariah Kamaruddin 


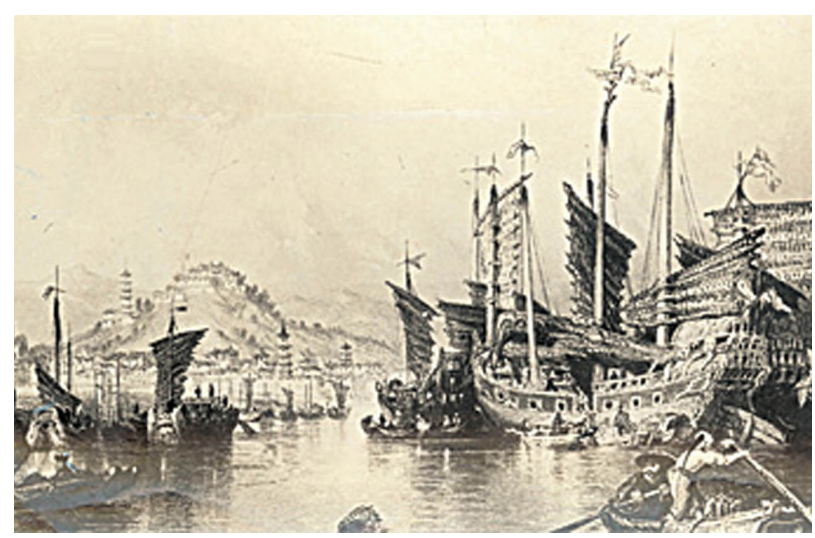

Fig. 1.1b View approaching Kota Melaka from the sea (source; William Bowman, 1999). Indicative of settlements along the coast dotted by mosques and minaret towers with houses built up the hill slope and the istana at the top of the hill with open ground in front of it of an open view towards the harbor and the open sea where all the foreign ships anchored

Fig. 1.1b Widok na Kota Melaka od strony morza (źródło: William Bowman, 1999). Widoczne osiedla wzdłuż wybrzeża, zarysowane meczety i minarety pośród domów wybudowanych na zboczu wzgórza oraz istana (pałac) na szczycie; przed pałacem niezabudowana przestrzeń, nic nie zasłania widoku na przystań i otwarte morze, gdzie zakotwiczone były wszystkie obce statki

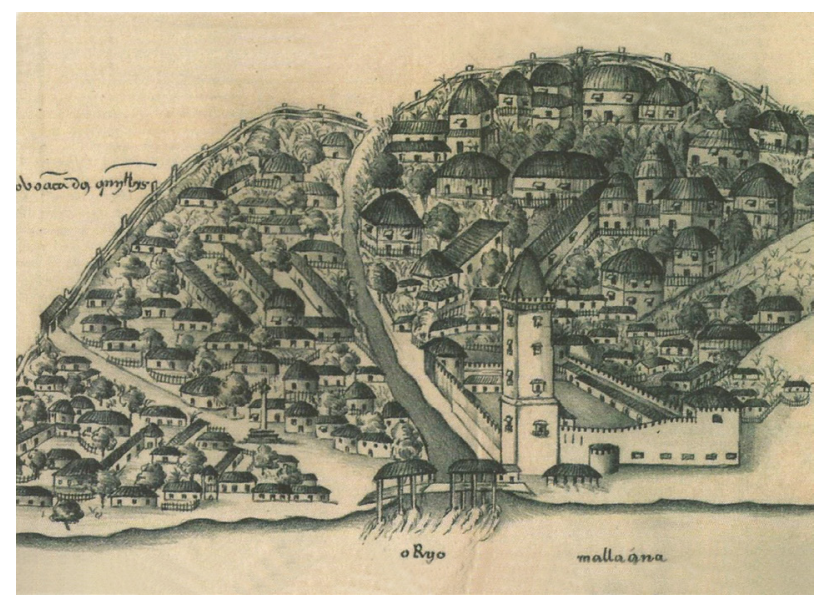

Fig. 1.1c An illustration of Melaka city just after the Portuguese's conquest (extracted from Bosworth, 2007, Historic Cities of the Islamic World, pp. 315-330). Front Cover Clifford Edmund Bosworth BRILL, 1 Jan 2007

Rys. 1.1c Ilustracja przedstawia miasto Melaka krótko po zdobyciu przez Portugalczyków (źródło: Bosworth, 2007, Historic Cities of the Islamic World, ss. 315-330), okładka: Clifford Edmund Bosworth BRILL, 1.01.2007

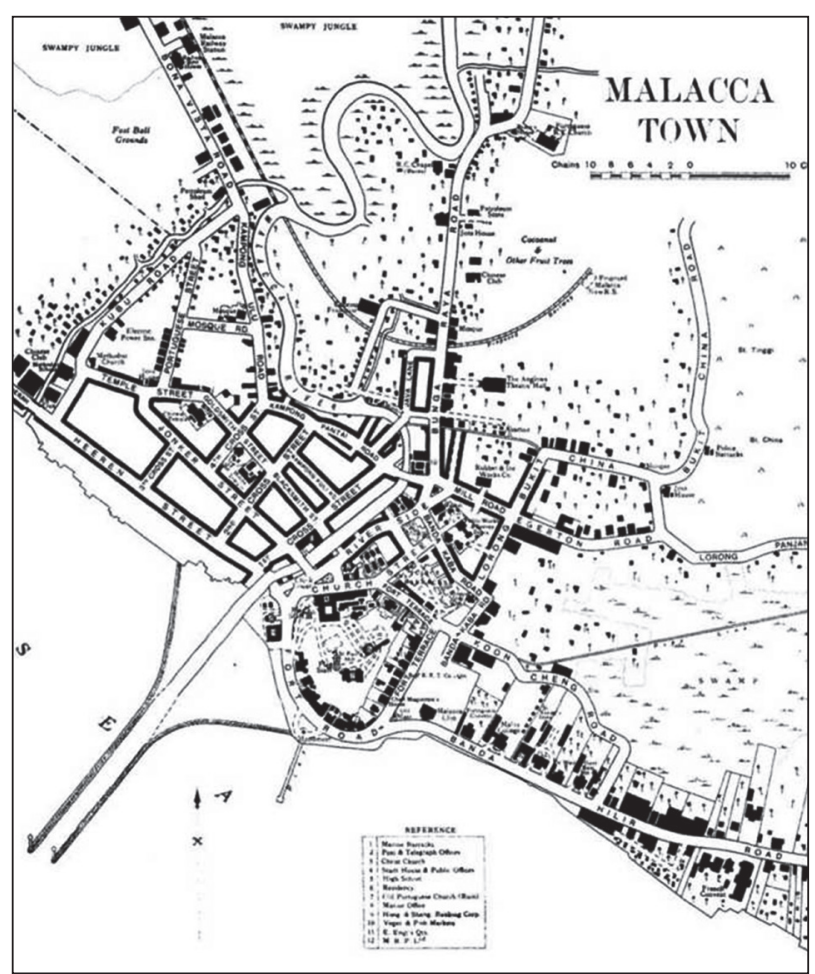

Fig. 1.1d Map of Melaka of the Dutch era indicating gridded zoning (Source: Cornell University Digital)

Rys. 1.1d Plan Melaki z okresu holenderskiego, pokazujący podział na strefy (źródło: Accessed from Columbia University)

taic plain, allowing ships to easily navigate and berth (across centuries sedimentation had continued at the river mouth and the shoreline has changed). The original pattern of Melaka has been attempted to be reconstructed by Jahn Kassim and Kamariah (2018), Widyamoto (2016), etc. Below, in Figure 1.1a, there is the latest mapping of the urban core of Melaka, following earlier studies and attempts.

Figure 1.1c above is indicative of the location of the mosque which is by the river and Figure 1.1d shows the structure pattern of Kota Malaka when overlaid over the first image. The harbor side is structured in its compact neighborhood pattern while the estimated palatial complex, though axial in its orientation towards the harbor, its surrounding neighborhood is organically loose in its pattern facing the water be it coastal or river front.

This painting (fig.1.1e) provides an indication for mapping out the Istana complex at the top of the hill, where St. Paul Church is now located, and aligned with the mosque at the foot of the hill by the river and the covered bridge. 


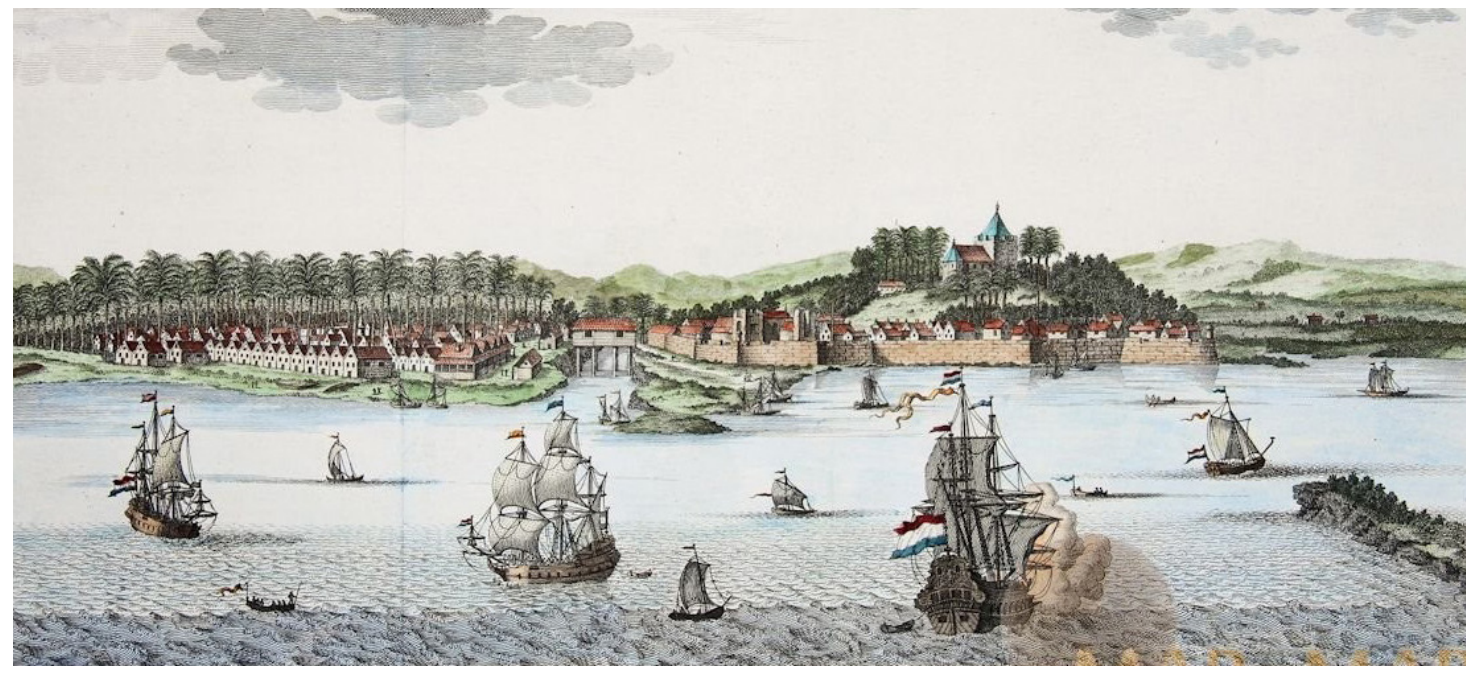

Fig. 1.1e Engraved map of Dutch Malacca by the cartographer Nicolas Bellin 1754. The map is an original map with hand col-oring and showing in bird eye view the fortification of Malacca with Dutch VOC ships in the foreground. Source: https:// www. mapandmaps.com/en/archived-maps/4879-dutch-malacca-malaysia-old-map-voc-ships-malaka-bellin-1754.html

Fig. 1.1e Rycina przedstawiająca Melakę pod panowaniem holenderskim, autorstwa kartografa Nicolasa Bellina 1754. Rycina jest oryginalną mapą, ręcznie kolorowaną i pokazującą z lotu ptaka widok fortyfikacji Melaki z holenderskimi statkami Kompanii Wschodnioindyjskiej na pierwszym planie. Źródło: https://www.mapandmaps.com/en/archived-maps/4879-dutch-malacca-malaysia-old-map-voc-ship-s-malaka-bellin-1754.html

\subsection{Seri Sayung, Kuala Kangsar}

The precolonial urban core of Perak was centered at Kota Lama Kanan (see fig. 1.2a and 1.2c) as the first royal centre of Perak (1528) was to be known as Istana Sri Sayung.

Figure 1.2d is the illustration which the mapping of Sri Sayong is based on, and it suggests an image of a royal neighborhood of which to the left is the place where the istana complex could have been (see Fig 1.2f) indicated by bamboo reed fencing, with the residence of the kerabat diraja - royal families within close proximity and the mosque centrally located, bounding the padang in front of it for easy access from the river as a public assembly area. The river then was very much part of the Malay economic livelihood, as a source for food as floating marketplace and as communication and transport highway (F. McNair 1887).

F.McNair (1887) had described the villages of Perak, as urban centers situated on various rivers $(1.2 \mathrm{e}$ and $1.2 \mathrm{~g}$ ) and Sungai Perak, as the highway to the sea, which became the means by which the people obtained the supplies. He further added: 'the exceedingly picturesque appearance of a Malay village with the river flowing before it, of a cluster of houses of bamboo and other

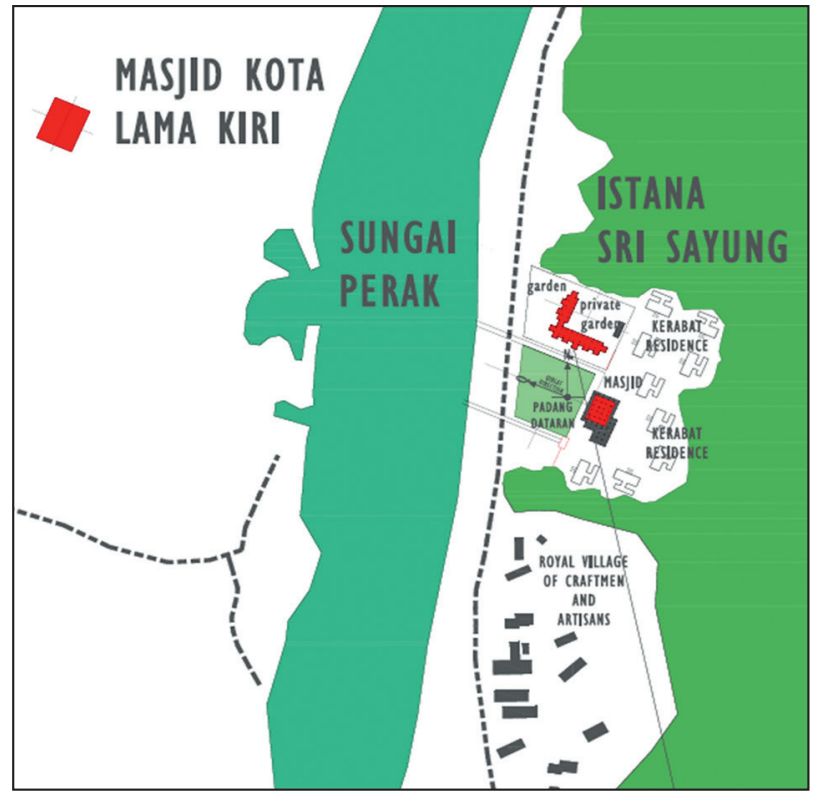

Fig. 1.2 Estimated pattern of the first royal center of Perak, Istana Seri Sayung (1528) at Kota Lama Kanan, an estimation of orientation and configuration

Rys. 1.2. Mapowanie pierwszej królewskiej siedziby w Peraku, Istana Seri Sayung (1528) w Kota Lama Kanan, oszacowanie orientacji i konfiguracji oraz zespół urbanistyczny Chadan na wzgórzu (malajska nazwa: bukit) 


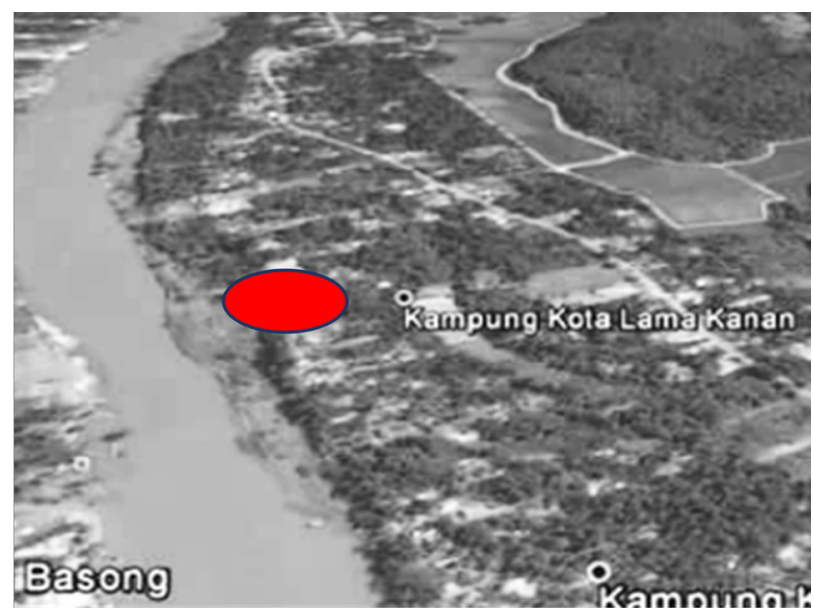

Fig. 1.2a Site estimation of the first istana complex of Sri Sayong (1528) located on the flat plain along the river bank of Sungai Perak with dusun - orchards and rice growing field straddling the riverbank to the foothill and the mountain as the backdrop of the region of Perak

Rys. 1.2a Przybliżone miejsce pierwszej siedziby kompleksu istana w Sri Sayong (1528) umiejscowionym na równinie na brzegu rzeki Sungai Perak, z sadami (dusun) i polem ryżowym, rozciągającym się pomiędzy brzegiem rzeki a podnóżem góry, oraz górą dominującą na horyzoncie w regionie Perak

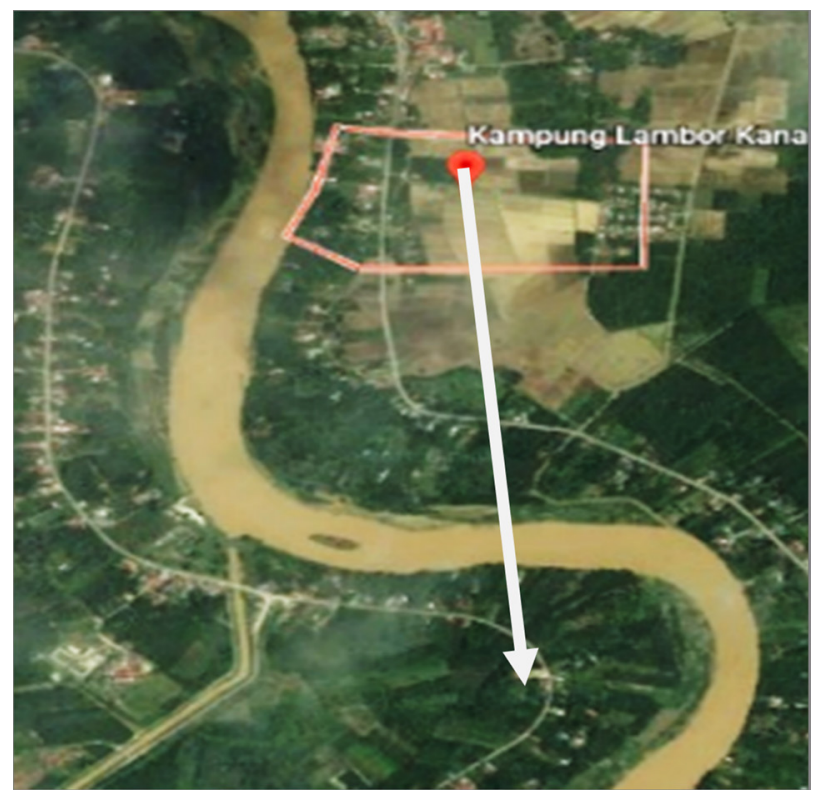

Fig. 1.2b Due to recurring floods the royal centre was relocated to higher grounds of Bukit Chandan and remained so till today

Rys. 1.2b Z powodu powtarzających się powodzi, centrum królewskie przeniesiono do Bukit Chandan, gdzie istnieje do dziś

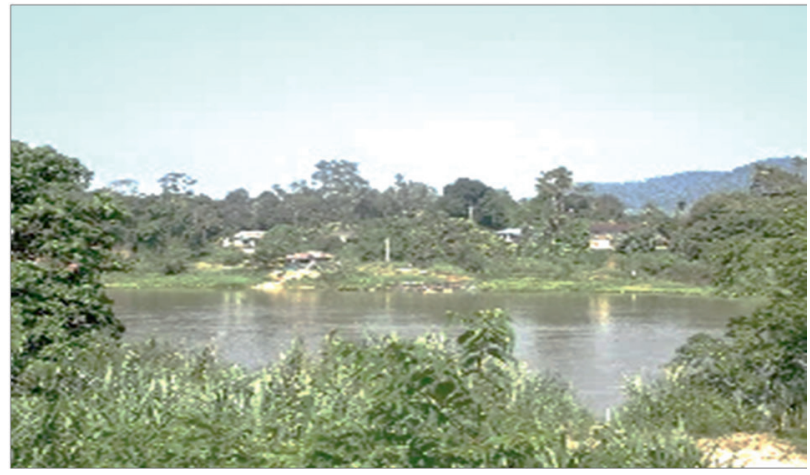

Fig. 1.2c The abandoned site of Kota Lama Kanan, burnt down by the British in the last war with the local Perak Malay Rys. 1.2c Opuszczona osada Kota Lama Kanan, spalona przez Brytyjczyków w czasie ostatniej wojny z miejscowym Perak Malay

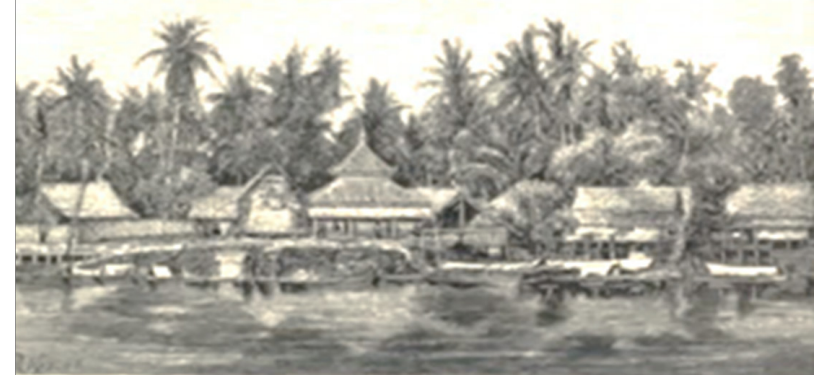

Fig. 1.2d An illustration of the settlement that suggests a royal neighborhood (source F. McNair 1887)

Rys. 1.2d Ilustracja osiedla sugerująca królewskie sąsiedztwo (źródło F. McNair 1887)

wood, and the masjid as its centre and amongst its palms and other fruit trees shading the quaint bamboo palm-thatched structures as being pleasing in the extreme: and the boats, secured to bamboo posts, or run up safely on the mud that played a prominent part in the daily life of the people, and the roads were of a few elephant-tracks but little used, and pathways through the jungle known to the country people alone... '

Thus on the right bank of Sungai Perak just north of Kuala Kangsar; within the flat plain of Lembah Sayung (fig. 1.2a) is the first royal center named Sri Sayung (1528) which was relocated to the hilltop of Bukit Chandan (1778), south of Kuala Kangsar. The original site was abandoned and named Kota Lama Kanan after the war of the Perak Malays and the British Residencies (fig. 1.2b) F. McNair (1887). 

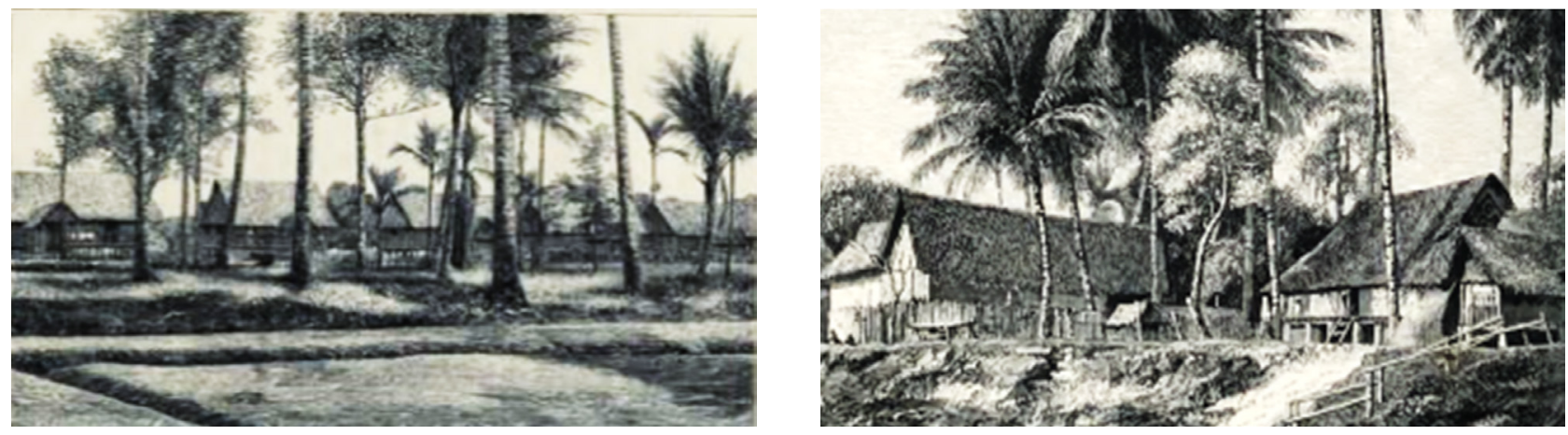

Fig. 1.2e (left) The village as urban centers dotted along the banks of Sungai Perak that serve as highway upstream to the hinterland and downstream to the sea and $\mathbf{1 . 2 f}$ (right) the residence of a noble chief (Source: F. McNair 1878)

Rys. 1.2e (po lewej) Wioska, która podobnie jak ośrodki miejskie, położona jest wzdłuż brzegów Sungai Perak, służących jako droga w górę w głąb lądu, a w dół - do morza oraz 1.2f (po prawej) rezydencja naczelnika wioski (Źródło: F. McNair 1878)
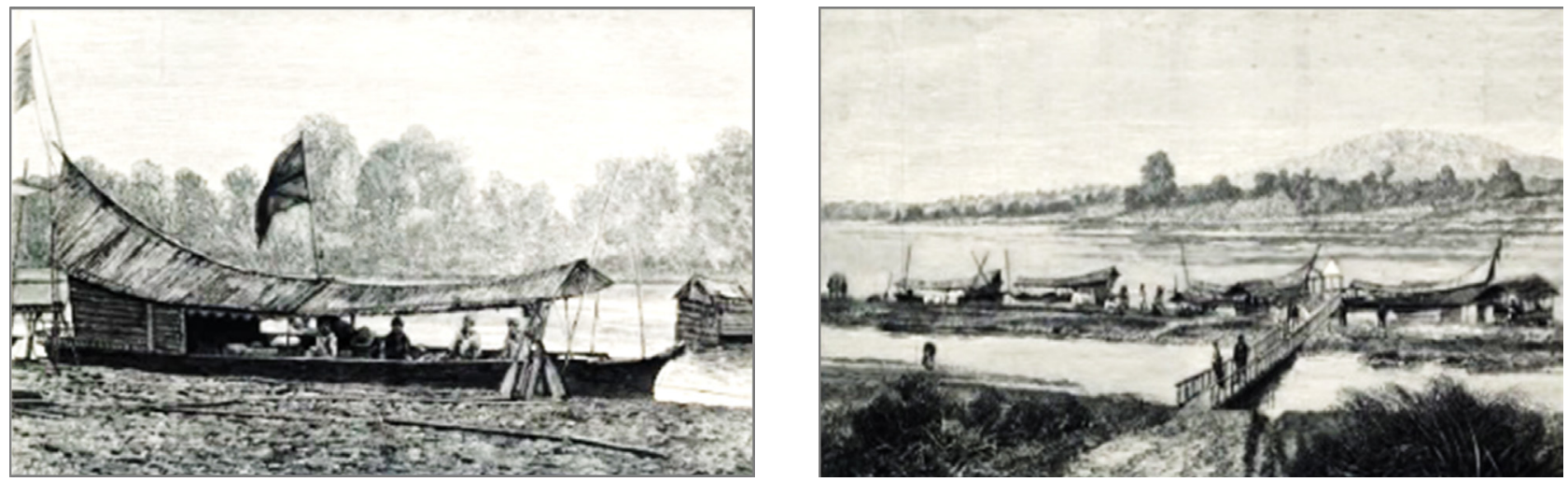

Fig. 1.2g Sungai Perak, the scene of economic activities and market place on floating markets (Source: F. McNair 1878) Rys. 1.2g Sungai Perak, scena przedstawiająca działalność gospodarczą na targu na lądzie oraz na wodzie (Źródło: F. McNair 1878)

The public realm during this era was is the water way of Sungai Perak as that was the public highway then; where most of the economic activities took place on boats, and the floating market would be a scene inseparable from the Sungai Perak (Fig. 1, 2b) the main pathway that parallels the river from other village centers strung along the river upstream and downstream lead to the padang of Sri Sayung; bounded by the natural landscape that form the back drop of Sri Sayung $(1.2 \mathrm{c}$ and $1.2 \mathrm{~d})$ and the interfacing elements that include 1) the bamboo fencing surrounding the istana and its gateway entrance formally facing the padang expressing the centrality of the istana. 2) the intricate bamboo side wall façade (palm and bamboo are the main village building materials (F. McNair 1878) and 3) the anjungportico of the istana to receive guests; directly opposite the gateway suggesting focal intent.
Due to recurring floods, the royal center was relocated to higher grounds of Bukit Chandan (see fig. 1.2b) of which colonial influence was very much involved in its planning with an open ground surrounding the palatial complex and the mosque areas.

\subsection{Alor Setar, Kedah}

Founded in 1735 as the $8^{\text {th }}$ Administrative Center of Kedah, by the $19^{\text {th }}$ Sultan of Kedah, Sultan Muhammad Jiwa Zainal Adilin Mu'adzam Shah (1710-1778) (W. S. M. Yusof (2014), Alor Setar is located inland by the right bank of the river, accessible around the sharp bent where the water terminal was located accessing direct on to the padang; and alongside the terminal, the masjid; and across the padang to the east. The Balai Besar was oriented at such an angle and aligned with the 


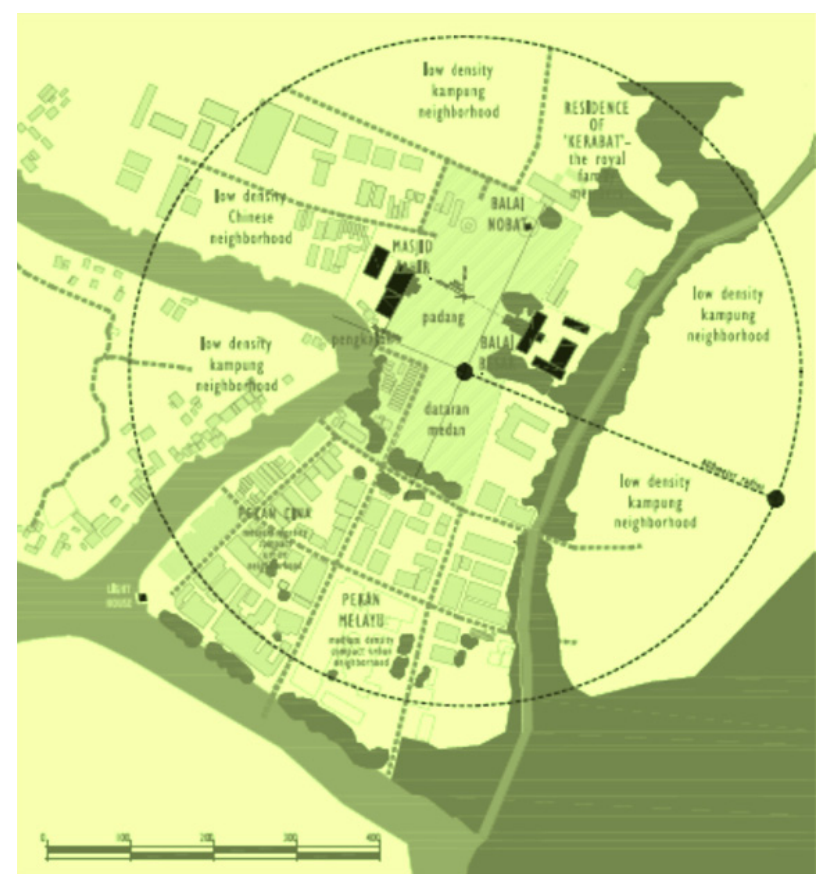

Fig. 1.3a An estimation of Alor Setar traditional urban core and zoning component by the $18^{\text {th }}$ century $(1710-1778)$ Rys. 1.3a Plan tradycyjnego miejskiego centrum Alor Setar oraz komponentu strefowego w XVIII w. (1710-1778)

masjid so as to capture the prevailing winds of NE and $\mathrm{SW}$. The configuration is focal with the padang in the center, the Balai Besar to the east and the masjid to the west, the metropolitan commercial center to the south; bounded by the green and alor - stream to the east; the river to the south and west and the kampung neighborhood beyond. The public realm includes pathways that lead to the padang often shaded with large trees, thus providing cool shady walking bounded by shaded structures. The public realm also included the waterway as journey travelled to experience the tapestry of the water's edge of the greenery, kampung neighborhoods that appeared from the green scenery that displayed language of climatic origin, serene and blending with nature.

\subsection{Kadariah, Pontianak}

Pontianak is located by the river Kapuas. It is comprised of the recurring components of the traditional urban center - the istana and kediaman kerabat - residence of the royal family, the padang and the masjid Optimally oriented to capture the SW and NE prevailing winds though not aligned with the masjid qiblat direction, but it faces the masjid directly. Linear in configuration with the public realm, it spans and provides a physical and visual link between the istana and the masjid; from the padang or dataran located at the anjung of the istana where public audience is received and thus formed the public front of the istana and to the masjid grounds where the Medan - the open market is often located. The street as public realm is heavily shaded with trees on each side of the street and bound by the façades of the masjid and the istana and in between the façade elements of residential buildings on each side of the street filtered by big trees with its surrounding semi enclosures of spaces such as the serambi - verandah, tembok - fence wall, solid or perforated, and the gateway to mark the entrance. Focal in nature - the anjung of the istana becomes the focal public front.
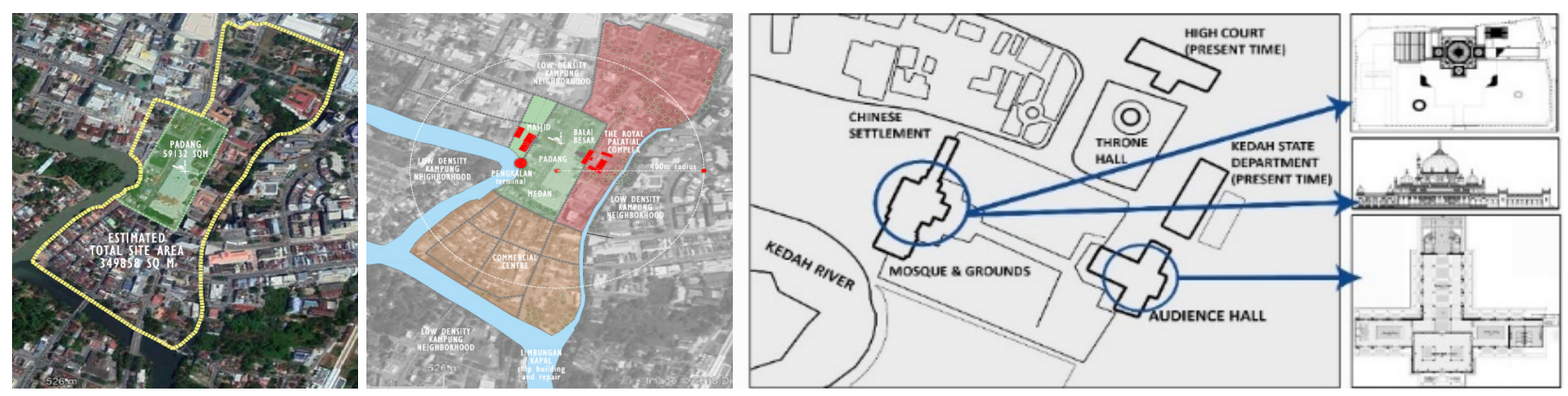

Fig. 1.3b The original public - civic realm of the Malay town of Alor Setar, including the symbolic open space before Colonial incursion that constitute an open 'padang' seen as the uniting factor that hold the mosque and the istana together, focalized as one entity

Rys. 1.3b Powyższe zobrazowania opisują kolejno oryginalną przestrzeń publiczną miasta przed inwazją kolonialną. Przestrzeń składa się z otwartego placu zwanego padang, który jest czynnikiem integrującym przestrzeń, gdzie znajduje się meczet i pałac, wyglądające jak jednolita struktura 

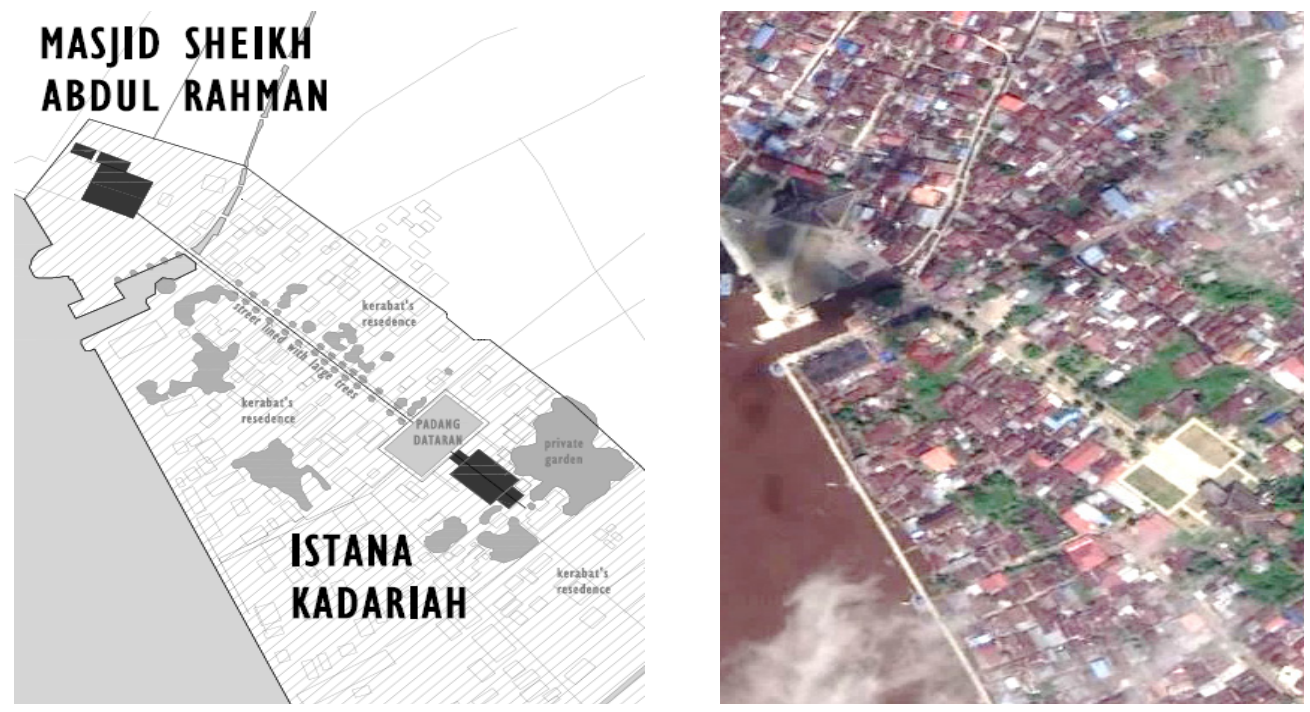

Fig. 1.4. Istana Kadariah and the mosque (1770s) - The continuity between palace and mosque in precolonial urban core of Pontianak estimation and postcolonial pattern (present)

Rys. 1.4. Istana Kadariah (lata 70. XVIII w.) - przedkolonialna i postkolonialna

\section{PUBLIC REALM ORIENTATION, CONFIGURATIONS AND LOCALIZED WIND PATTERNS}

8.1. The palatial orientation as in the case of Kota Melaka estimated through past lithographs and documents, and 'petua melayu', is optimized to capture prevailing NE and SW wind from which the configuration took advantage of the hill as the royal administrative center and residence of the royal family members, with a commanding view over the strip that form the public realm, i.e. the river, the covered bridge that housed some twenty retail plot, the trading port and that include the commercial center and metropolitan neighborhood and the main trading open market on the harbour side, and the spatial strip along the water's edge often dotted with large tree to provide shade; the Medan - open market or square, part within the palace complex such as the masjid and the Balai Besar. This public realm extends further into the commercial compact neighborhood as courtyards and the low density kampung neighborhood as halaman rumah - house compound and masjid/surau grounds. The main palace was found to face the bridge which aristocratic structures facing the river and the mosque. Some were optimized to capture prevailing winds of the north easterly and south westerly and often massed and configured in a linear tiered roof building form to facilitate wind driven ventilation and comfort. Table 2 below high-lights the horizontal and vertical configuration of these palaces as illustrated with plans, elevations and sections and wind roses. In all four cases the solution to comfort is similar; linear building form with kolong - under floor space and tiered roof of Bumbung Panjang or Bumbung Limas.

The kolong has developed into a permeable under-floor zone below the public spaces of the istana, to allow ventilation and also to serve as spaces to hold public function. These zones typically would spill over to the Padang, and visually link with the masjid and its related serambi-verandah ways of the masjid that form shaded space of the public realm. These areas i.e. the serambi - verandah ways are typically enhanced with the infusion of symbolic patterns by the craftsmen and artisans center often located at the front boundary if not attached to the kolong of the kampung unit, and served as shops to display their crafts work and products, as sundry shops for daily supplies or as eateries.

8.2. The public - realm configuration is focal in terms of a compact center. In the case of Sri Sayung, the padang is centrally located and directly accessible from the river and the main pathway; with the Istana to the north and masjid to the east and behind it the kerabat - royal family residence and the craftsmen/ artisans center to the south (fig. 1.2, 2.2). 
Water and natural landscape is part of the scene of the Perak public realm which highlight how the water ways were particular to the urban design features of the Malay world.

Horizontal (Figure 2.1) and vertical Configuration (Figure 2.1a) of Kota Melaka is reconstructed reflecting how the fort of the city was essentially square, before it became octagonal after Portugese and Dutch colonisation. The urban core depicts a linear tiered mass form facing the river and kiblat direction, demonstrating how the vertical and spatial morphologies have evolved essentially in synchronisation with climatic and topographical character. A comparison and juxtaposition was undertaken between the estimated orientation of the key buildings and the local wind directions of site obtained from the local meterological weather stations. It can be seen that many of the structures, were optimally directed for comfort ventilation.

\section{KOTA MELAKA}

\section{Horizontal configuration}

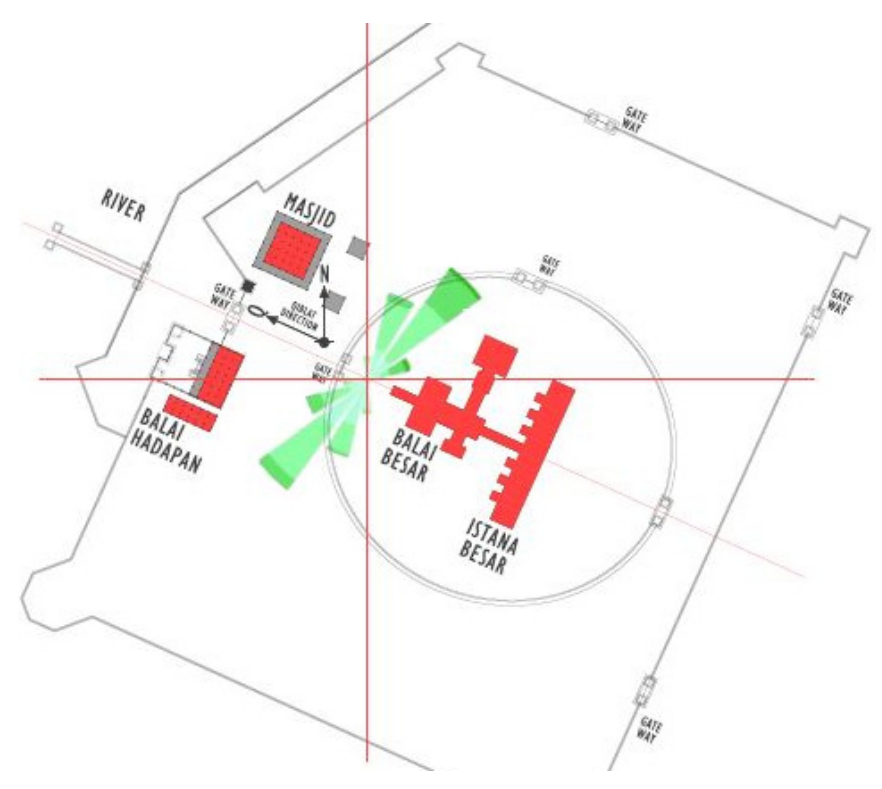

Fig. 2.1. Reconstruction of the urban core pattern of Kota Melaka (1511) and when superimposed on the local wind rose demonstrate how the palace massing accurately the capture of NE and SW winds (@ Kamariah Kamaruddin)

Rys. 2.1. Kota Melaka (1511) plan miasta nałożony na różę wiatrów, aby dokładnie pokazać, że dominują kierunki NE i SW (C) Kamariah Kamaruddin)

\section{Vertical configuration}

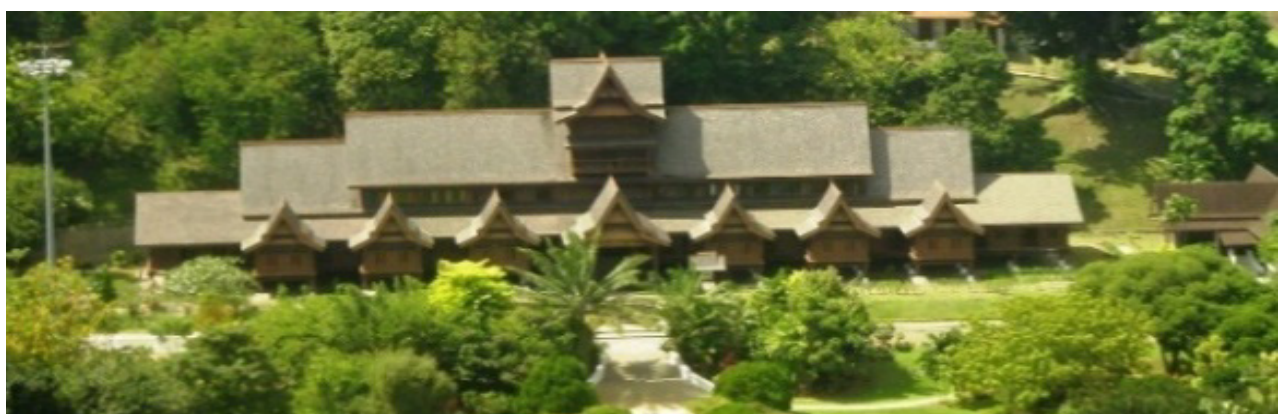

Fig. 2.1a. The essentially elongated massing of the palace is suited to enhance wind driven ventilation which can be of horizontally and vertically facilitate through the Melaka palace vernacular form. linear building, mass tiered roof form and the kolong - floor underspace

Rys. 2.1a. Naturalna wentylacja wietrzna w kierunku poziomym i pionowym możliwa jest poprzez liniowe usytuowanie budynku, masywny dach warstwowy, zapewniający przewiew pomiędzy przestrzenią pod dachem (kolong) a podłogą 


\section{SRI SAYONG KUALA KANGSA}

\section{Horizontal configuration}

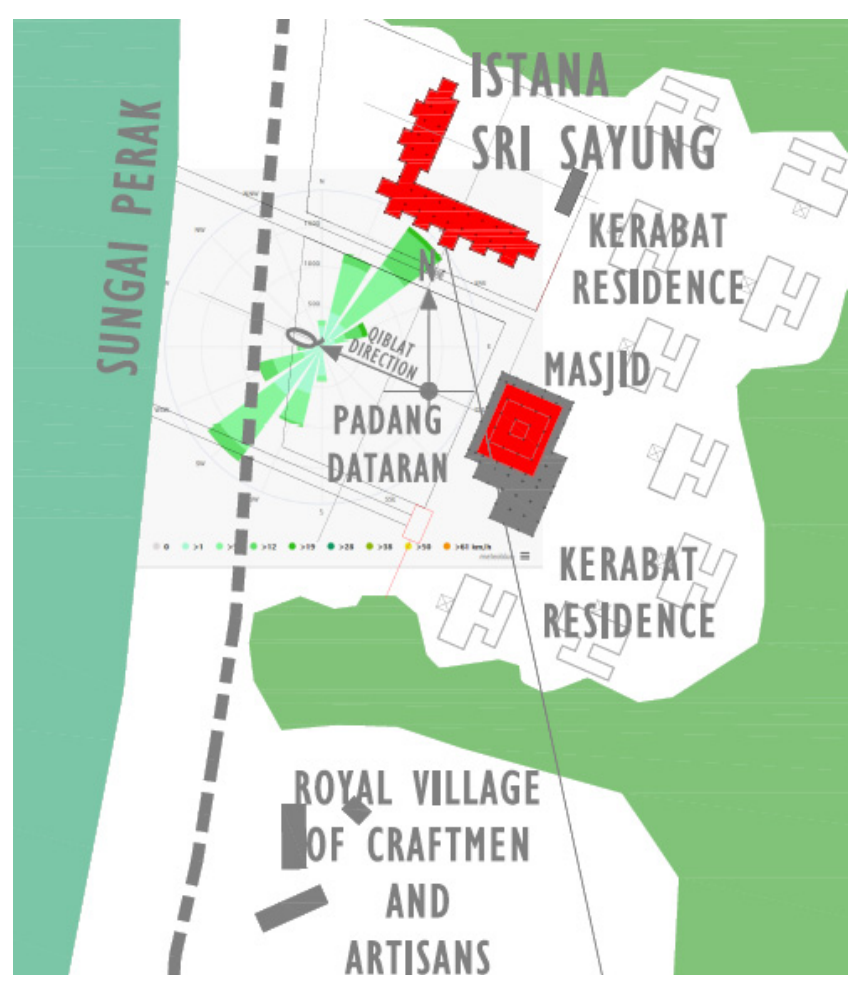

Fig. 2.2. Sri Sayung (source: McNair 1878) estimated as an L Shaped structure as observed in Mcnair's sketch and superimposed on wind rose to capturing prevailing wind

Rys. 2.2. Sri Sayung (źródło: McNair 1878) uformowana w kształcie litery L, jak to widać na szkicu Mcnaira nałożonym na różę wiatrów pokazującą dominujące kierunki wiatru

\section{Vertical configuration}

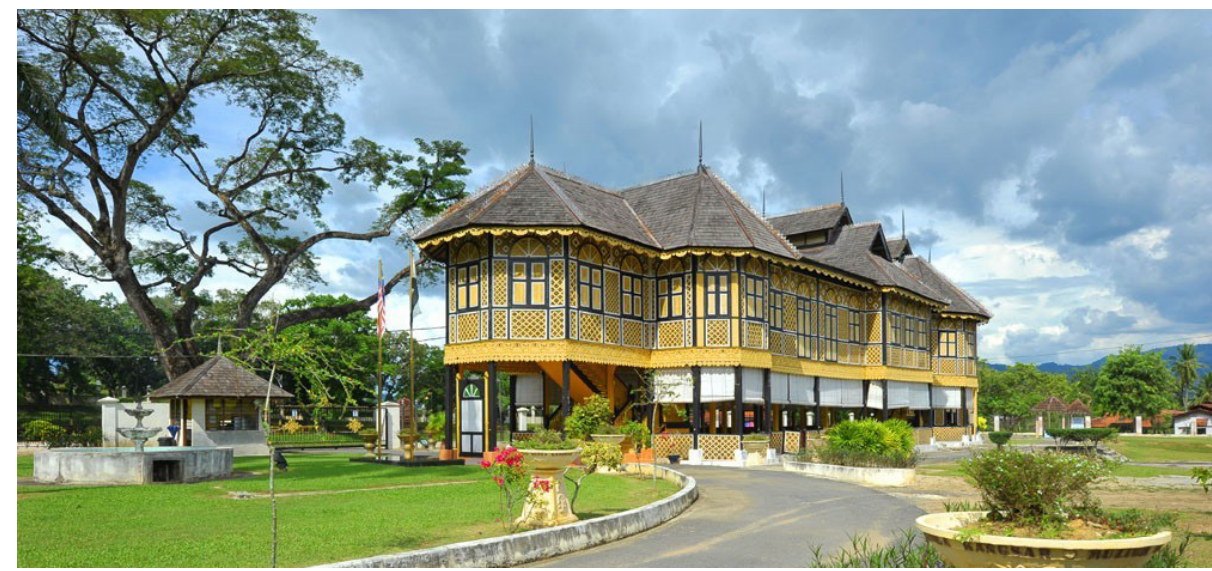

Fig. 2.2a. The present Istana Kenangan, with its linear building form with kolong-under floor space and roof form suggest the past from of the original Sayung complex (Source: McNair (1878). Perak and the Malays: 'Sarong' and 'Kris')

Rys. 2.2a. Istana Kenagan, z widocznym liniowym kształtem budynku, przestrzenią kolong pod podłogą i dachem, co zapewnia naturalną wentylację. (Źródło: McNair (1878). Perak and the Malays: ‘Sarong' and 'Kris') 


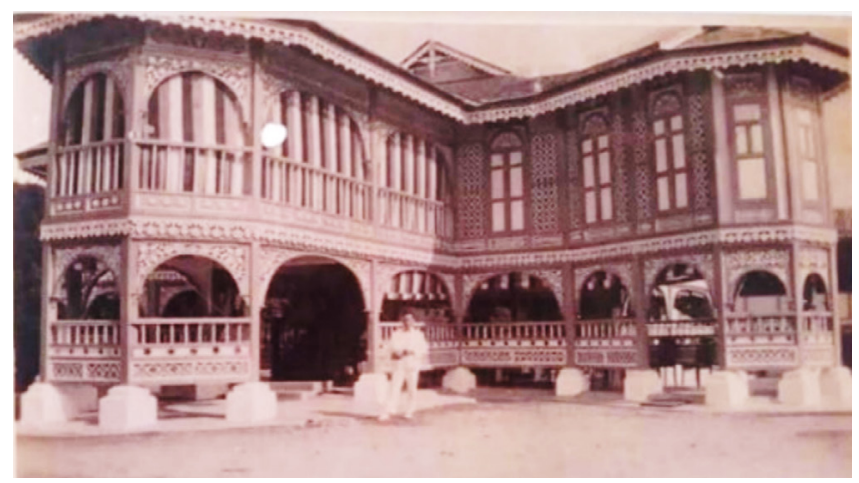

Fig. 2.2b. Istana Sri Sayung, was believed to be relocated to Bukit Chandan site (1887) was later renovated and named "Istana Lembah", reconstructed and renovated with its climatic essence preserved the linear building form and bamboo side wall façade and the kolong - underfloor space hence hence suggesting wind driven principles princoples was used to achieve comfort and renamed Istana Negara. This istana was later demolished, and replaced with Istana Iskandariah (1932)

Rys. 2.2b. Pałac Istana Sri Sayung przeniesiony do Bukit Chandan (w 1887), odbudowana z odtworzeniem dostosowanej do klimatu liniowej struktury i bambusowej struktury fasady i ścian oraz kolongu - przestrzeni pod podłogą umożliwiającej naturalną wentylację dla zapewnienia komfortu. Nazwę zmieniono na Istana Negara. Później pałac ten rozebrano i zamieniono na Istana Iskandariah (w 1932)

\section{ALOR SETAR, KEDAH}

\section{Horizontal configuration}

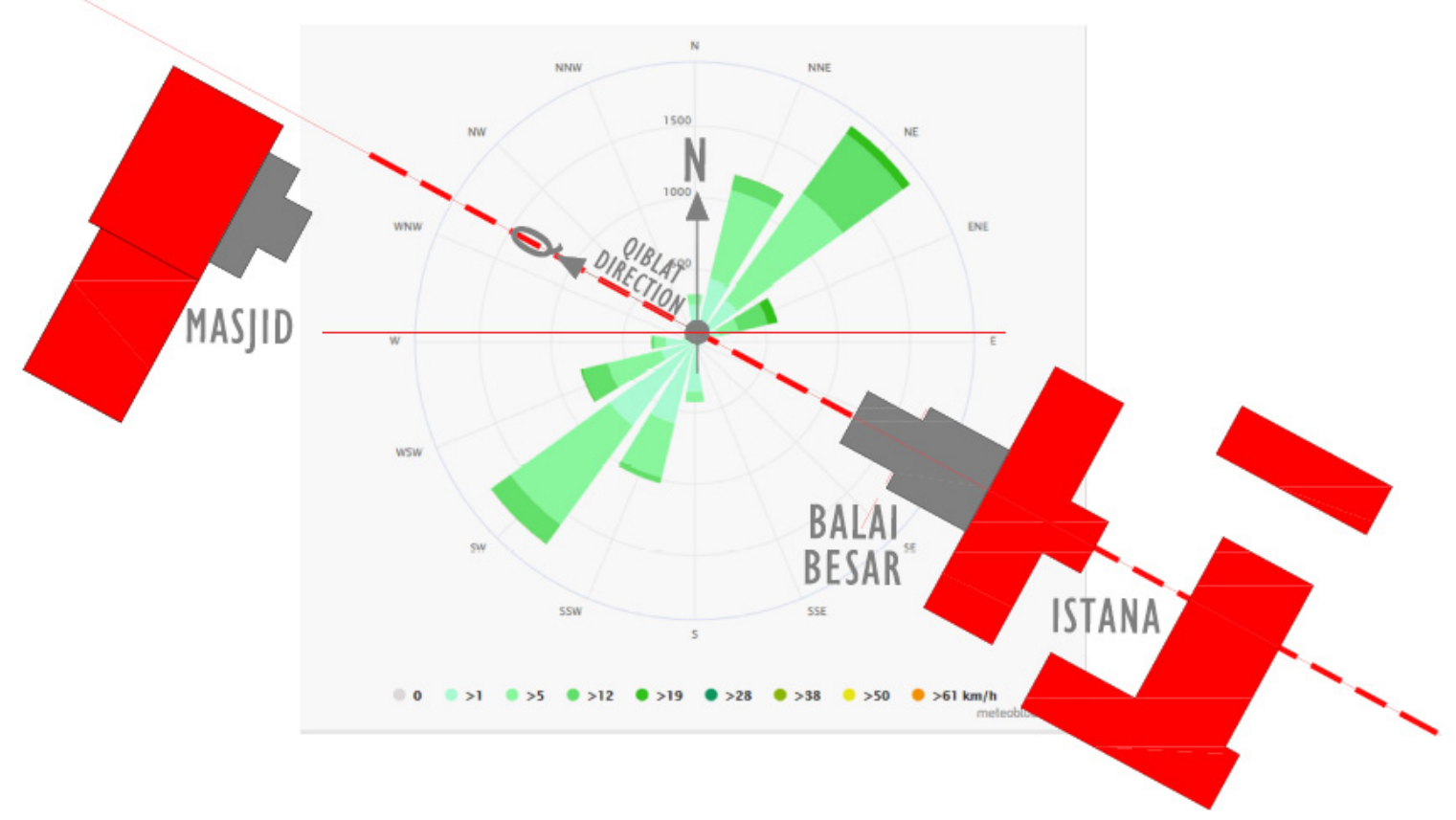

Fig. 2.3. Alor Setar Balai Besar (1735 to 1896) - orientation of palace and mosque showing the optimum massing to wind flow Rys. 2.3. Alor Setar Balai Besar (1735-1896)

\footnotetext{
${ }^{1}$ It cannot be ascertained at this stage that this is physically the original Sri Sayong but a discussion by royalists and historians that there is a high possibility that this is the original Sri Sayong is found here (https://sembangkuala.wordpress.com/2011/10/23/a-quandary-part-2-an-istana-in-kuala-kangsar-c-1927/
} 


\section{Vertical configuration}

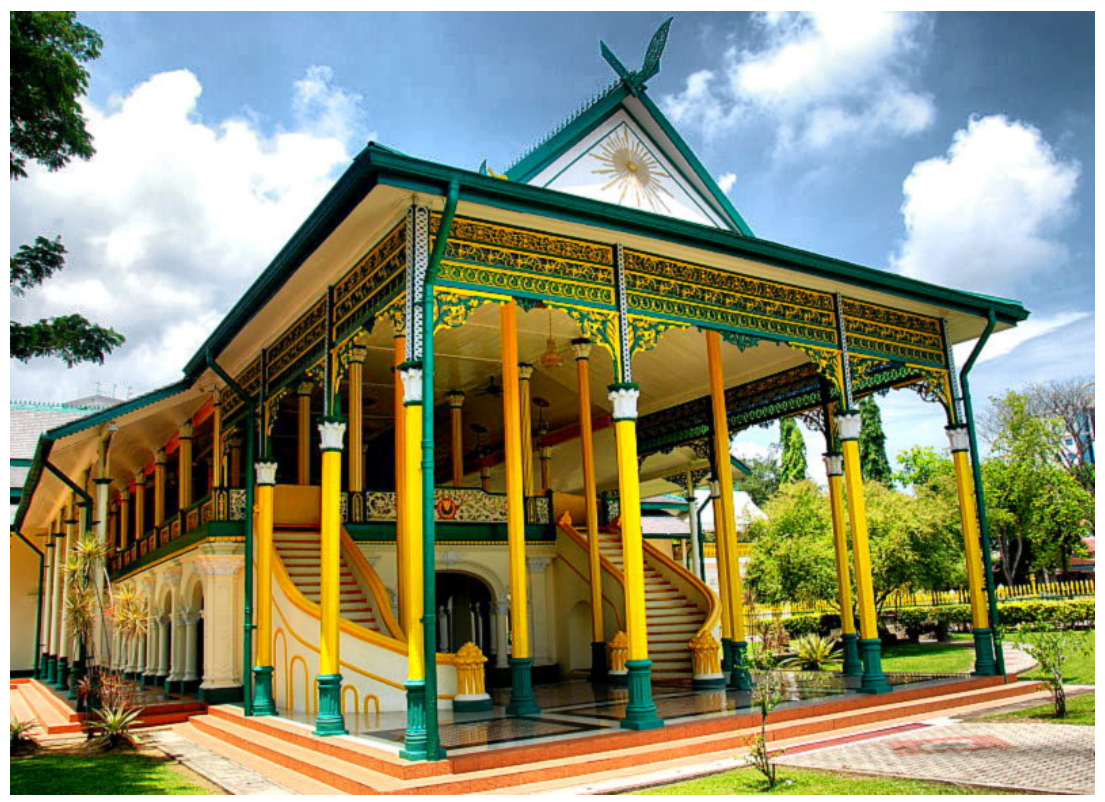

Fig. 2.3a. The present renovated Balai Besar demonstrate the use of kolong and combination of bumbung limas/panjang Rys. 2.3a. Balai Besar wykazuje użycie kolongu w połączeniu z bumbung limas/panjang

\section{KADARIAH, PONTIANAK}

\section{Horizontal configuration}
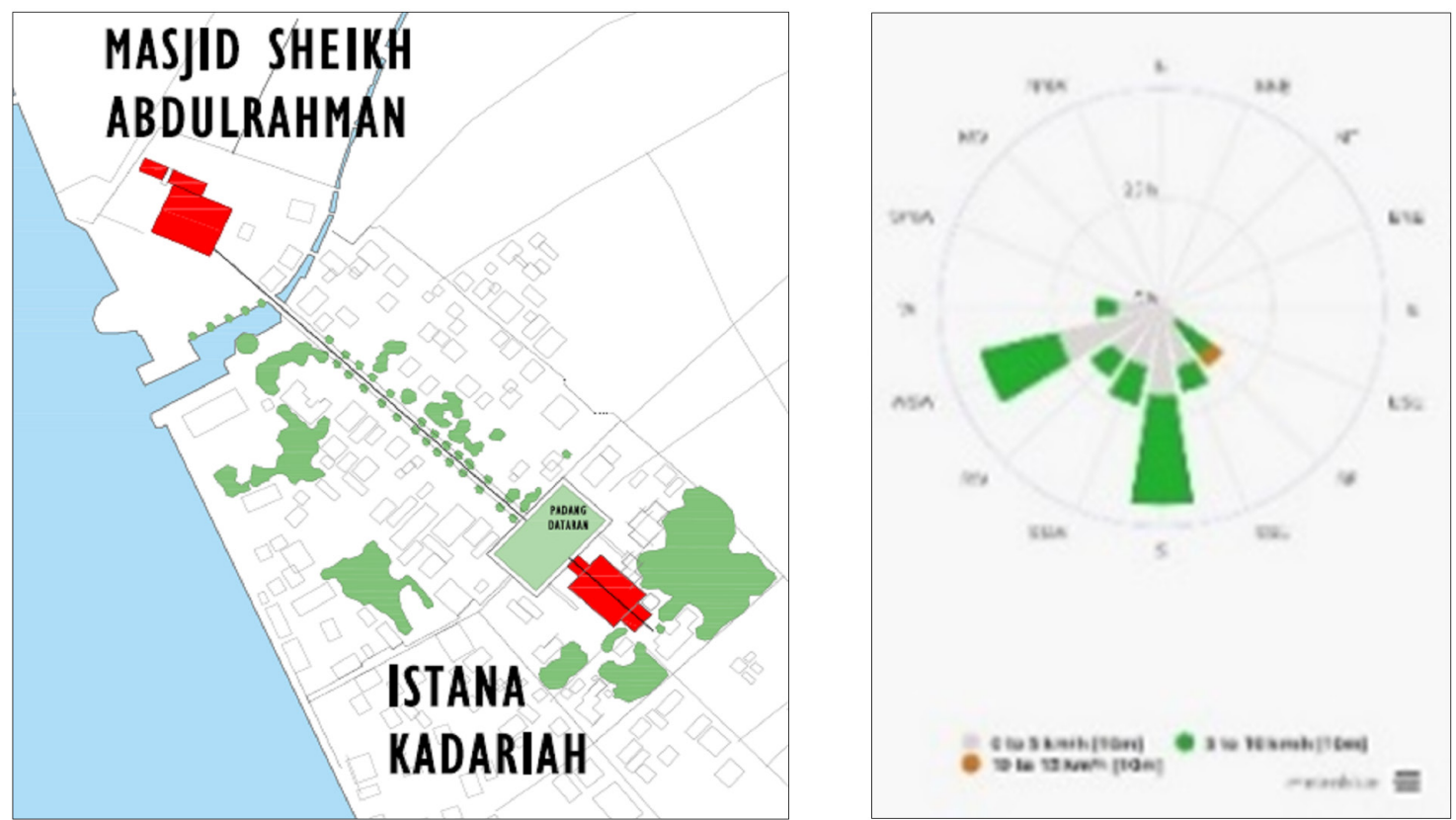

Fig. 2.4. Istana Kadariah, Pontianak layout super imposed on the wind rose indicate maximum capture of prevailing wind from the river side

Rys. 2.4. Istana Kadariah, Pontianak nałożony na różę wskazującą, że dominują wiatry od strony rzeki 


\section{Vertical configuration}

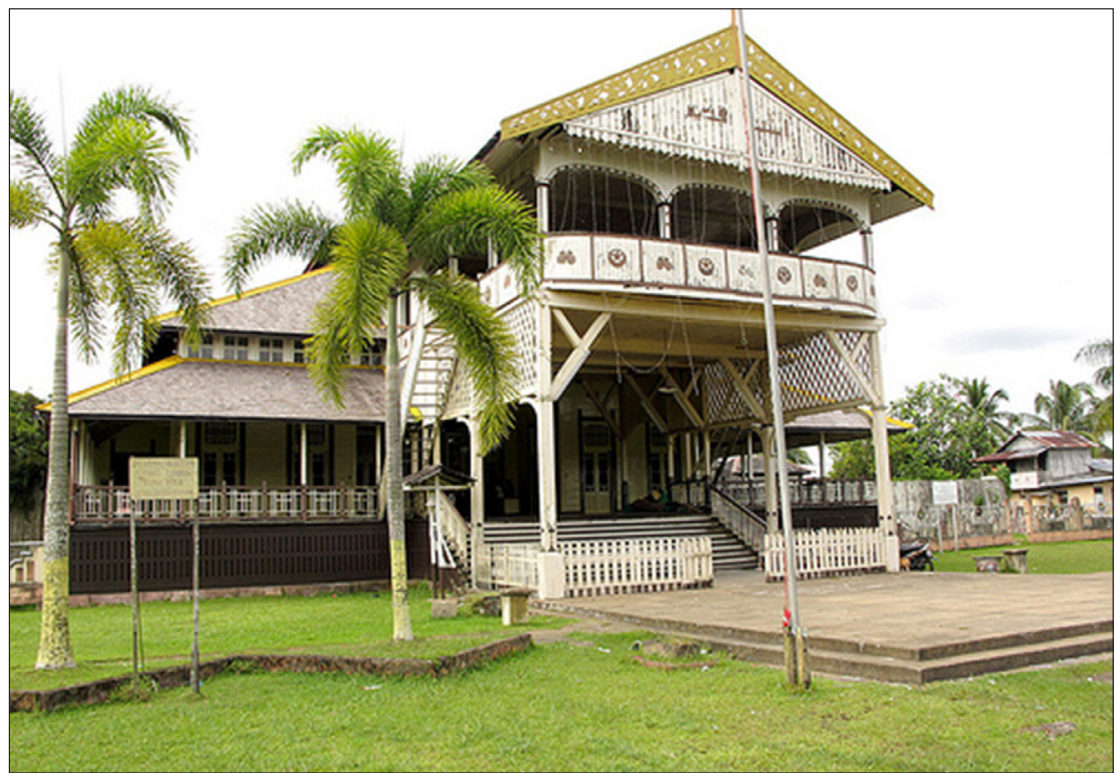

Fig. 2.4a. Istana Kadariah Pontianak with kolong at ground level, verandah at upper level and mass tiered roof to the entire length of building that facilitate wind driven ventilation and maximum turfed ground surface prevent buildup of heat island and surface water runoff. (Source: flicker images)

Rys. 2.4a. Istana Kadariah Pontianak z kolongiem na poziomie przyziemia, werandą na wyższym poziomie i masywnym dachem warstwowym na całej długości budynku, ułatwiającym naturalne przewietrzanie, oraz powierzchnią gleby maksymalnie pokrytą darnią, co zapobiega tworzeniu się wyspy ciepła i odpływowi wody. (Źródło: portal flicker)

\subsection{Urban core configuration - Aspect of the colonial era}

Below there are the modeling and reconstruction of postcolonial urban configurations, which essentially can be described as more dispersed, lack-ing the past traditional urban compactness and intimacy and which no longer consists of an integral combination of pal-ace-mosque complex.

\subsubsection{Melaka}

Compared to Figure 1.1. The colonial patterns below represent a ruptured and dispersed form of city, whereby colonialism has caused the past unified form of the urban core to be affected or basically divided into two clear segments.

\subsubsection{Kadariah, Pontianak}

The present palace of Kadoriah, still recall the past 'compact' public realm and similar to Melaka, it is divided by a river.

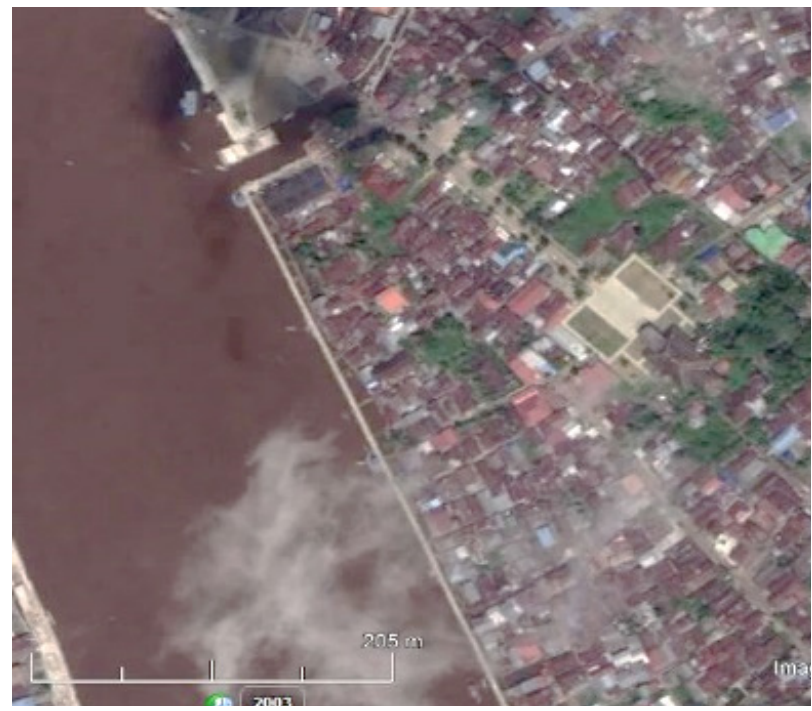




\subsection{Gardens, Pools of trees and Open Spaces}

Landscape formed an intrinsic part of the traditional Malay World that has been passed from one kingdom to the next and the existence of pools under large trees in the Malay Sultanate centers is prominent. Nasir, (1981) and Abdul Rahman al-Ahmadi (2003) described how the royal palace of Malacca Sultanate had extensive open grounds planted with groups of bamboo with slits cut in it at the main entrance gates, combined with a line of palm trees along the fence. At the front of large gardens located at the sides of the palatial buildings had flourished with a variety of trees and open spaces that served a number of functions with different types of garden functioned for both utilitarian and ornamental purposes.

Inherited by the Perak Sultanate, Kuala Kangsar was a royal center located inland with a different geographical setting where the Sungai Perak being the exclusive highway to the sea for economic activities and a market place for exchange of goods and the plain of wilderness was as vast as the naked eyes could see, the river became the public realm and the garden concept and sanctuary is adapted to a much broader context and thus reflected in the orchards clustered along Sungai Perak and the vast plain jungle of Perak as the source of food supply, herbal and medicinal plants and building materials, thus the wilderness became the emporium for such local needs, as well as a sport hunting ground. As described by F. McNair (1878): 'Perak was just plain jungle, for the Malay is most apt in the way in which he utilises the abundant materials that nature has placed to his hand'.

The extension of the wilderness of gardens, pools and tree shades into the village urban centers is a characteristic pattern of the Malay sanctuaries that have significant impact on the micro climate. The halaman of kampung unit, strung right through leading to the open spaces of urban core were organic in its pattern, tree lined and bounded by buildings enveloped in interfacing bioclimatic features, hence making distance travelled comfortably cool and walkable. While the first layer of kampung unit was arranged to face the river to take advantage of the cool breezy air over the water, the inner layer would have the kolam ikan - fish pond or telaga - a well, built to specified location as prescribed by 'petua melayu' including the type of fragrant flowering plants, fruit trees and shaded trees to be planted (Ahmadi (2006) on the halaman - compound of the kampung or aristocrat units.
The transect through the traditional city from the kampung unit to kampung neighborhood, through to the palatial complex and the commercial center of compact neighborhood; blended in the natural elements the river, pool and trees which phenomenally impacted microclimate of the traditional urban core and enhance the environmental quality of the public realm.

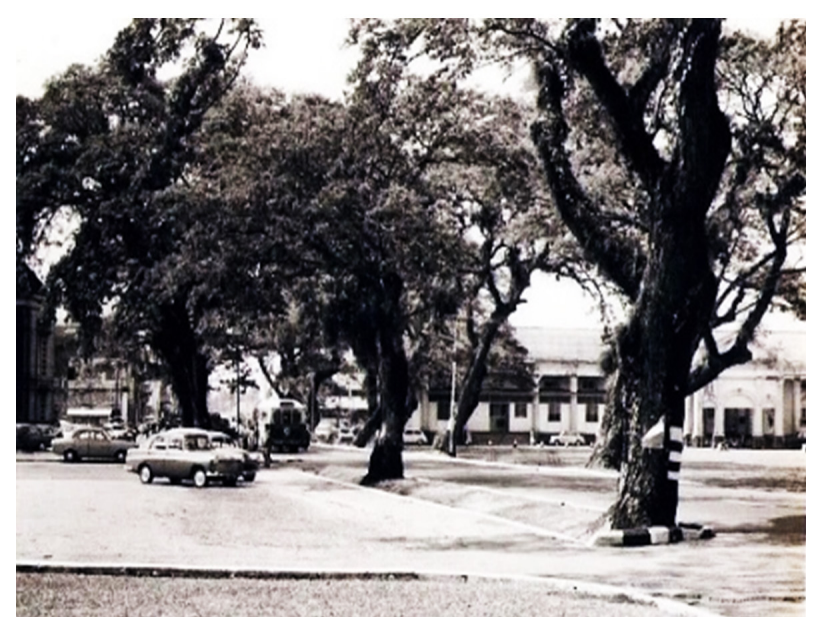

Fig. 2.5a. Original tree lined street in Alor Setar, in front of the royal palace

Rys. 2.5a. Oryginalne zadrzewienie ulicy w Alor Setar, przed pałacem

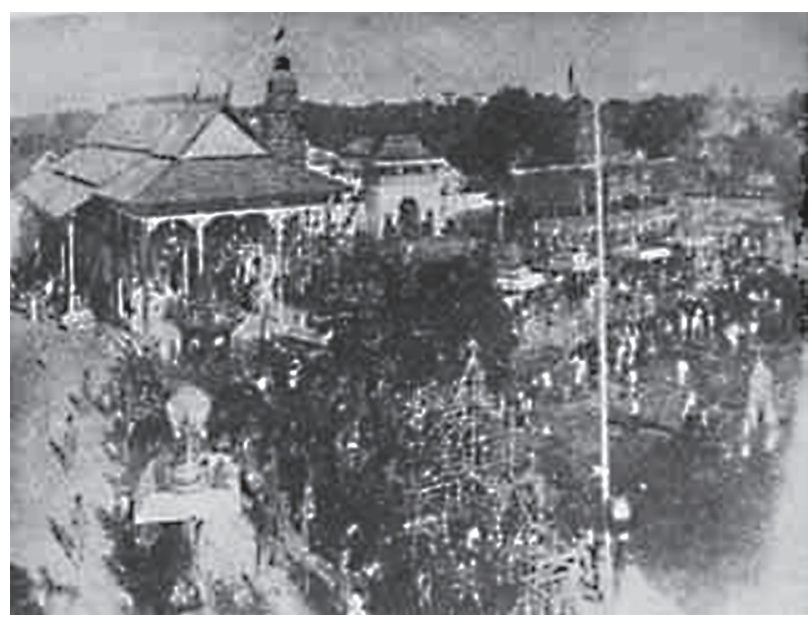

Fig. 2.5b. A photo taken in 1904 of a royal wedding showing the public space between at the Balai Besar and the multitude functional padang attended by the rakyat

Rys. 2.5b. Zdjęcie uroczystości weselnych w rodzinie królewskiej, wykonane w 1904. Widoczna przestrzeń publiczna pomiędzy Balai Besar i wielofunkcyjnym placem (padang) uczęszczanym przez lud (rakyat) 


\subsection{The urban grain and the river}
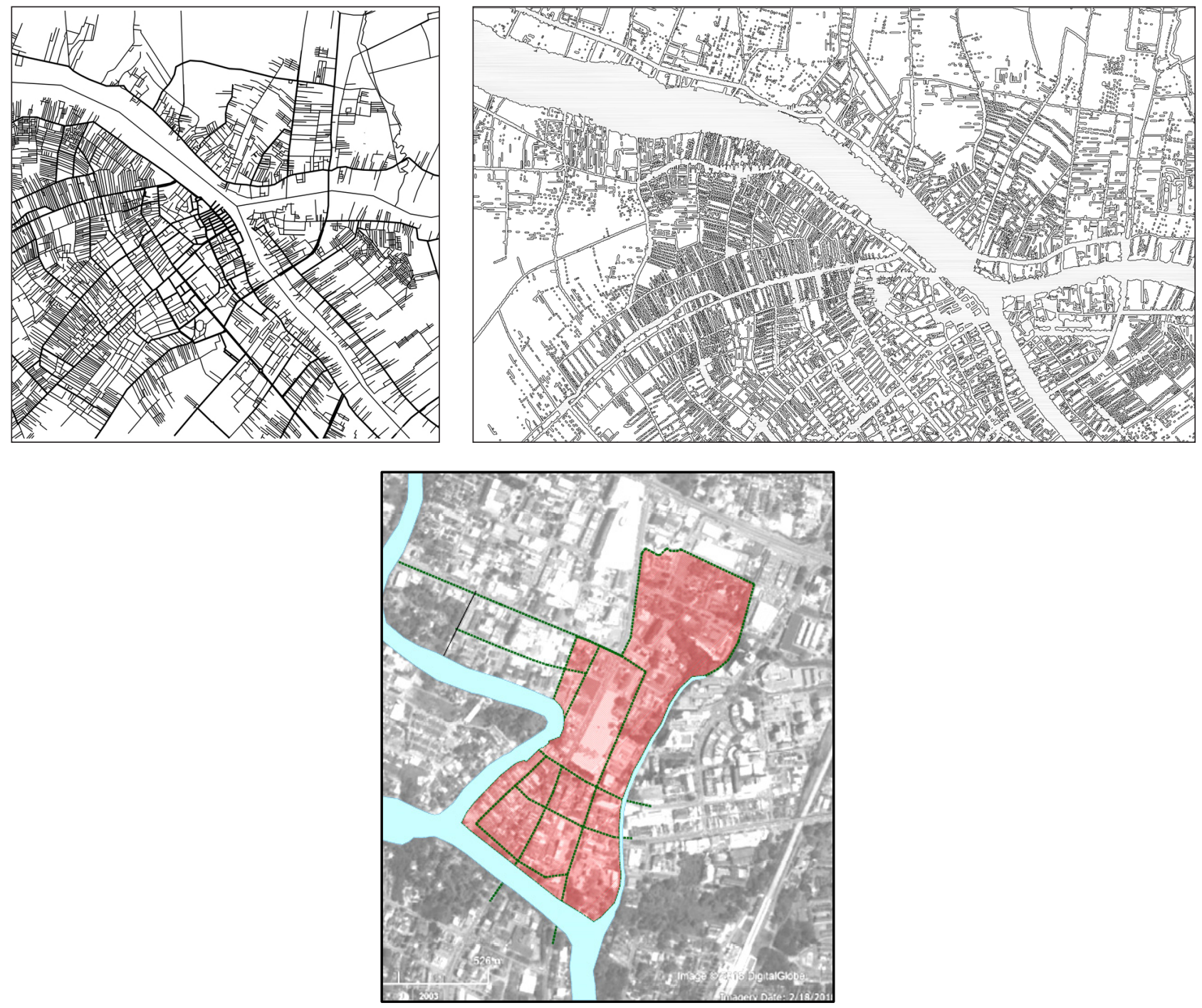

Fig. 3a (left), fig. 3b (middle) Urban grain of Pontianak Kalimantan indicating pathways parallel to the river with the house structures facing the water

Fig. 3c. Urban grain of Alor Setar which shows similar elements of river influences yet which have been affected by Colonialist interventions where roads cut through the grain. The pathways crossing the site are estimation of the original pathway

Rys. 3a (po lewej), Rys. 3b (w środku) Plan miasta Pontianak Kalimantan pokazujący drogi równoległe do rzeki i zabudowę zwróconą w kierunku wody

Rys. 3c. Plan miasta Alor Setar pokazujący elementy związane z rzeką, ale poddane wpływom kolonialnym, kiedy to drogi przecinały strukturę miasta. Drogi przecinające miejsce są przybliżeniem oryginalnych dróg

Past settlements around the river grew organically with the urban grains emerging perpendicular to the flow or the river and thus resulting ultimately grids perpendicular to the main river, rather than parallel with the houses and structures facing the river. While such urban morphology and patterns are now destroyed, layered by more linear and regimented colonial grids, many of the urban grain can no longer be seen. In certain Malay towns such as Pontianak, Kalimantan, in which location and historical background was irrelatively isolated from colonial influences and impact, such river-influenced grain and grids can still be observed. 
Tab. 1. Proposed matrix of the characteristics of a Malay public realm impacting climatic and environmental sustainable criteria and targets

Tab. 1. Proponowana macierz cech malajskiej przestrzeni publicznej, z uwzględnieniem kryteriów zrównoważenia ekologicznego, związanego z klimatem i celami działania

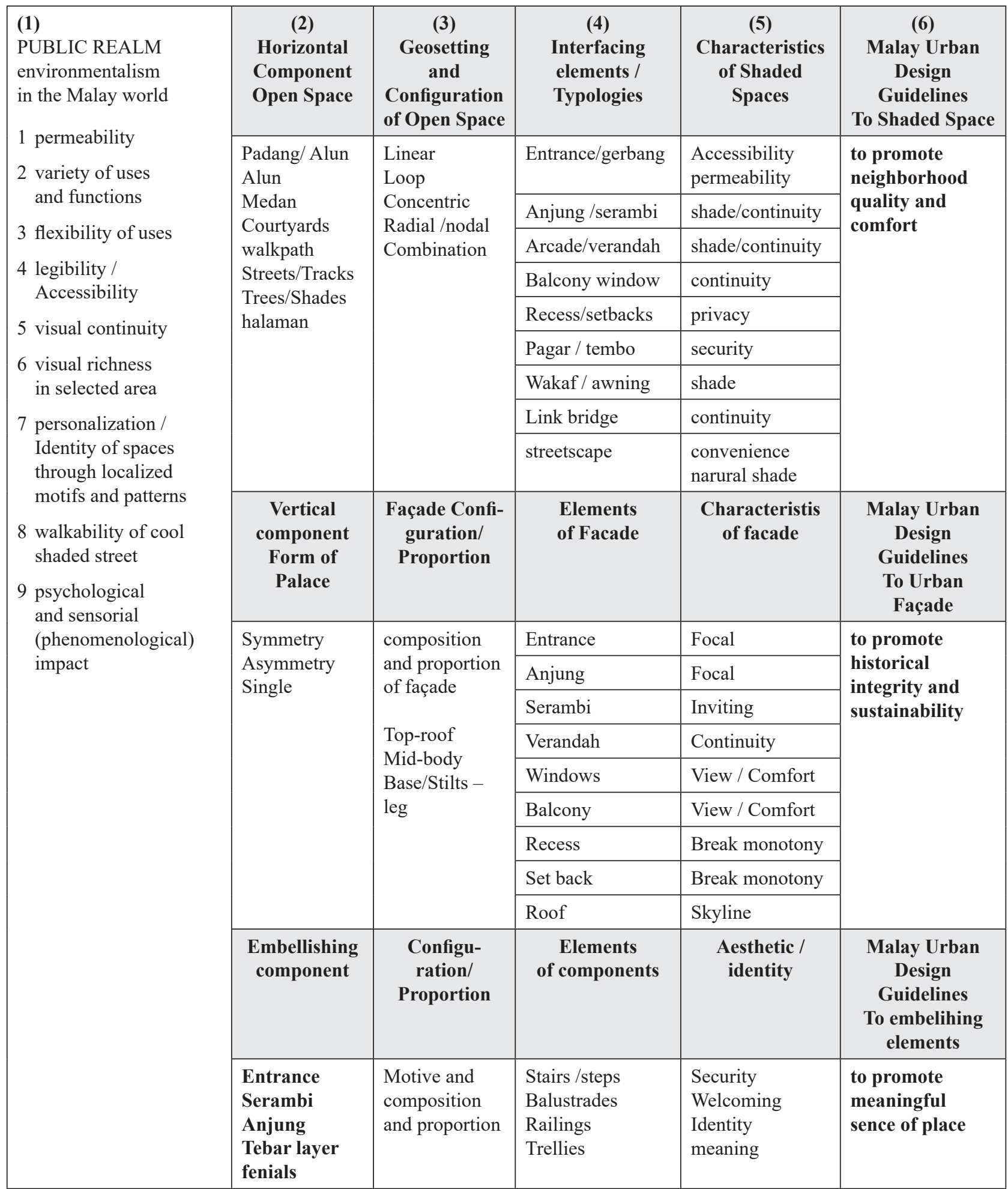




\section{FINDINGS}

Urbanization has now reversed these conditions into increasing concrete jungles that not only heat up during the day, but absorb large amounts of heat which is release at night, and over a long period of time. This paper is aimed at delving back into Malay vernacular settlements, particularly the urban core of precolonial time, in order to reengage with the climatic and environmental sensibilities of the Malay traditions. To achieve this, the paper looks at certain elements, principles and vocabulary derived from a morphological and typological study of Malay traditional urban centers in Malaysia and Indonesia, while the observation variations across the Malay world can further highlight how environmentalism and climatic sensibilities were much part of the Malay public realm and such strategies were implemented traditionally in public spaces particularly interfaces between public and private spaces in traditional times. The paper discusses these in terms of „vocabulary” of patterns, forms and shapes rather than merely broad principles and climatic data. From these studies, the climatic and environmental strategies and vocabulary of the public realm of the Malay world can be summarized as impacting of the following spaces and realms in the Malay world.

The findings drawn from these studies (Table 1.) suggest recurring common components (column 2) in the four traditional Malay kedatuan, geoset to face water body and kiblat direction and at the same time maxi mize the capturing of NE SW winds through its longest elevation orientation, configuration of each would differ slightly due to different location influenced by local terrain and setting (column 3) but principles remain the same. The same recurring elemental typologies (column 4) can be found and extrapolated in all the case study areas embedded with its environmentalist principles and characteristics (column 5) that are eco-climatically tropical, and parallels to the current green principles of present city building can be made.

\section{CONCLUSIONS}

Using both typological and morphological analyses of buildings and natural environment of case study sites, their urban core patterns are mapped and argued as a localized system or configuration reflecting the sustainable ethos of the past Malay world. A new ecological ethic and concept of tropical urbanism can arise. Morphological studies of maritime centers can reveal certain forms that are rooted to place yet which exemplify a tropical 'sustainable' urbanism. If implemented, they will have consequent cultural and climatic impact in comparison to present physical structures, architecture and urban features. The hypothesis is that the Malay Sultanate era evolved an optimum climatic and ecological form urban form particularly in the urban core of the Malay world. Their public architecture that forms the public realm, and is related to palaces, mosques and indoor-outdoor spaces was a part of such ecological urbanism. From the onset of colonialism, and its influence, the cultural setting slowly changed surreptitiously the morphological patterns of the traditional urban core and thus the need to unearth as these vernacular principles to be known as 'vocabulary' - tropical strategies that have remained to be adopted since the beginning of Colonialism in Malaya are to maximize climatic strategies in order to reduce the discomfort effects of the tropical climate.

The vernacular has been known as a source of sustrainable principles; yet an urban vernacular is less researched. yet crucial for the future of South East Asian cities, are studies to reconstruct the vernacular formations of the past in order to sustain the future. Ruptures caused by Colonialism; known as a force that caused a drastic effect on local regions.

Malay urban design principles arise from better morphological understanding are discussed. Results contribute to the localized notion of sustainability and the preservation of the authenticity of the urban core. Malay urban design principles, as abstracted from its traditional centers of built environment is part of the vernacular heritage of the region contain, certain wisdoms and ecological ingenuities which are crucial not only in fulfilling rising sustainable expectations and standards of the city, but contribute to its branding and heritage preservation

The period from 16th centuries to the mid-1800s onwards in South East Asian centers are of interest. Increasingly after this era, the Colonials had exerted a modernizing influence that had instigated an 'urbanizing' effect on vernacular forms and language of the region; yet some of the early patterns of the past are still traceable and available for study. These 'forms and urban elements constitutes thus a source of language and principles to create sustainable levels in rising Asian cities. This paper maps such vernacular sites, urban sit-in and landscape el- 
ements in order to create a range of urban elements with variations that contain underlying sustainable principles.

South East Asian cities have developed so rapidly that attendant theoretical and design framework - rooted in localised forms and vocabulary - are missing. Many new satellite cities and new eco-cities of Malaysia, Singapore, and Indonesia have green and high technology features imported externally yet lacking the attendant cultural resonances and memories. Sustainable urbanism, defined as a range of architectural and urban design elements that reflect a certain consciousness of, and consideration of the climatic and geographical identity of a region or a population, must also be an 'urbanism' that is defined as 'a way of life characteristic of towns and cities' and defined as 'a condition of permanence'. This has been linked to the role of the vernacular, in which the term 'vernacular' includes past city-like formations and structures, its functions, typologies and urban space configurations. The focus on palaces and public buildings are argued as crucial to urban forms of tradition, while in present cities, the key role of 'greenery and gardens' are crucial due to the rapid decimation of green elements through urbanization and concretization of tropical cities. It is the central issue of interest how such architectural forms contain and reflect the climate and culture and become an instigator of environmental best practice. Thus this research is an attempt to find such principles within the tradition of past architectural and urban language of the specific character of a tropical region, linked to its roots, traditions and culture to further shape the frameworks of urban design guidelines for the future.

\section{ACKNOWLEDGEMENT}

The authors would like to thank and acknowledge the Transdisciplinary Research fund (TRGS16-03-001 0001 - Characterization of Rules of Malay Architectural Language and Its Environmental Performance) from Ministry of Higher Education Malaysia (MoHE) for the support of this research.

\section{REFERENCES}

Yeang (1987), Tropical Urban Regionalism, Longman Publishers, Malaysia

Harun, Zalina and Abdullah, Alias (2018), 'Tropical green-ery and walkways in mediating identity' in 'Modernity, Nation and Urban-Architectural form', Pallgrave Mcmillan, United Kingdom
Kamaruddin et al. (2018), Accretion of the Nagara Form in Muslim South East Asia, in Proceedings of International conference on Heritage INHERIT 2018, Kuching, Sarawak

CAIRNS plan (2016), Planning Scheme Policy - Tropical urbanism, published by CAIRNS Regional Council, ver-sion 1.0

Carmona, Mathew (2010) Public Places, Urban spaces- the Dimensions of Urban Design, Routledge

Caliskan and Marshall (2011) Urban Morphology and Design Introduction. Built Environment, Vol. 37, No. 4

Leyden, John (2012) The Sejarah Melayu, Silverfish books Malaysia

Milner (2011) The Malays, Wiley Blackwell Publishers

Tarling Nicholas (1999) The Cambridge History of South East Asia, Volume one, Part one. From early times to c. 1500. Cambridge University Press

Gullick, J.M (1987) Malay Society in the late Nineteenth Century, the Beginnings of Change, Oxford University Press

F. McNair (1887) Perak and the Malays "Sarong and Kris": publisher, London Tinsley Brothers

Colombijn Freek (July 2004) Islamic influences on urban form in Sumatra in the seventeenth to nineteenth centuries CE, Indonesia and the Malay World 32(93): 249-270

Brown, M. Gordon, (1999) Charter of the New Urbanism, Congress of the New Urbanism, Edited by Michael Leccese and Kathleen McCormick, McGraw-Hill

Colquhoun, A. (2002). Modern architecture. Oxford University Press.

Alexander, Christopher, (1987) A New Theory of Urban design, Oxford University Press “... must recapture the process by which cities develop organically..." to create new theoretical framework, to remedy the defects of cities today.'

Samsuddin, N (2014), The Physical Design Atrributes of Traditional Malay Kampung in Kampung Tanjung Bunut, Kuala Terengnnau, IGCESH2014, Universiti teknologi Malaysia, Johor Bahru, Malaysia 19-21 August 2014 ' ... element of kampong and settlement, has not clear geometric order... and reflect organic character'

Jahn Kassim, S., Nawawi, Norwina, Abdul Majid, Noor Hanita (2016) The Resilience of Tradition, Malay Allusions in Contemporary Architecture. Areca Publishers. Penang. Measured drawings and Heritage Studies Heritage Report of Balai Besar, Alor Setar, Kedah. International Islamic University Malaysia. Kulliyah of Architecture and Environmental Design (KAED) IIUM Heritage Center 2005

Noor Hanita, Abdul Majid and Zuraini, D. (2014) Cultural Preservations through Digital Reconstruction of Baitul Anwar, Kuala Kangsar, Perak, Malaysia. IJSSH 2014, Vol. 4(5): 387-3

W. Shamsudin Mohd Yusof (2014) Kedah Dalam Warisan Sejarah dan Budaya Nusantara Koleksi Makalah 190

Nor Zalina Harun and Ismail Said (2014), The changing roles of public spaces in Malaysia, International Journal of Social Science and Humanity, Vol. 4, No. 5, September Clark, R.H., Pause, M. (2012) Precedents in architecture-analytic diagrams, formative ideas and partis. John Wiley and Sons 
Frampton, K. 1992. Modern architecture: a critical history (world of art). Theme and Hudson World of Art

Kusno, Abidon, (2010) The Appearances of Memory: Mnemonic Practices of Architecture and Urban Form in Indonesia, Duke University Press

Fadzidah Abdullah, et al. (2005) Measured drawings and Heritage Studies Report of Balai Besar, Alor Setar, Kedah. International Islamic University Malaysia. A report by the Kulliyah of Architecture and Environmental Design (KAED) IIUM Heritage Lab

Hans-Dieter Evers, Rüdiger Korf (2000), Southeast Asian Urbanism: The Meaning and Power of Social Space, LIT Verlag Münster

Eric C. Thompson (2004), Rural Villages as Socially Urban Spaces in Malaysia, Urban Studies vol. 41, no. 122357 -2376, November

Loukaitou, A. Sideris, and Banerjee, T. (1998). Urban Design Downtown: Poetic and Politics of Form. California: University California Press

Nor Zalina, H. and Ismail, S. (2008). Role and Fate of Padang in Malaysian Historical Cities. Proceedings of the 5th Great Asian Street Symposium. 5-7 December. National University of Singapore, Singapore
Nordin, H. (2004). Malaysian History from Dutch Sources: Two Colonial Port-Towns in the Straits of Melaka; Dutch Melaka and English-Penang. Kuala Lumpur: National Ar-chives of Malaysia.

Ooi, K.G. (2002). From Colonial Outspot to Cosmopolitan Centre: the Growth and Development of Georgetown, Penang from the Late 18th Century to Late 20th Century. Expanded Version of Paper Presented at the International Symposium on Urban and Architectural Histories under Colonial Rule in Asia. Geothe-Institute, 6-7 September 2000, Taiwan

Shuhana, S. (2011). Townscape Revisited: Unravelling Character of the Historic Townscape in Malaysia. Malaysia: Penerbit UTM Press

Widya Fransiska Febriati Anwar (2013). Identification of the Morphological Characteristic of Palembang Riverside Settlement. Faculty of Built Environment Universiti Teknologi Malaysia

Clifford Edmund Bosworth (2007), Historic Cities of the Islamic World, BRILL

Reid, Anthony (2012), South East Asia - at critical crossroads, Wiley Blackwell.

Andaya, Leonard (2010) Leaves of the same tree, NUS Press, Singapore. 